\title{
Detrital zircon ages from Neoproterozoic and Early Paleozoic conglomerate and sandstone units of New Brunswick and coastal Maine: implications for the tectonic evolution of Ganderia
}

\author{
Leslie R. Fyffe ${ }^{*}$, SAndra M. BarR ${ }^{2}$, Susan C. Johnson ${ }^{3}$, Malcolm J. McLeod ${ }^{3}$, \\ Vicky J. McNicoll ${ }^{4}$, Pablo Valverde-Vaquero ${ }^{5}$, Cees R. van Staal ${ }^{6}$, and Chris E. White \\ 1. Geological Surveys Branch, New Brunswick Department of Natural Resources, P.O. 6000, Fredericton, New Brunswick E3B 5H1, Canada \\ 2. Department of Earth and Environmental Science, Acadia University, Wolfville, Nova Scotia B4P 2R6, Canada \\ 3. Geological Surveys Branch, New Brunswick Department of Natural Resources, P.O. 5040, Sussex, New Brunswick E4E 5L2, Canada \\ 4. Geological Survey of Canada, Ottawa, Ontario K1A OE8, Canada \\ 5. Instituto Geológico y Minero de España, La Calera 1, Tres Cantos, Madrid, Spain \\ 6. Geological Survey of Canada (Pacific), Vancouver, British Columbia V6B 5J3, Canada \\ 7. Nova Scotia Department of Natural Resources, P.O. Box 698, Halifax, Nova Scotia B3J 2T9, Canada \\ * Corresponding author:<les.fyffe@gnb.ca>
}

Date received: 24 February 2008 Date accepted: 07 September 2009

\begin{abstract}
Detrital zircon ages were determined for conglomerate and sandstone samples from six fault-bounded belts in New Brunswick and coastal Maine. Formations sampled included the Martinon (Brookville belt), Flagg Cove (Grand Manan Island belt), Matthews Lake (New River belt), Ellsworth (Ellsworth belt), Calais (St. Croix belt), and Baskahegan Lake (Miramichi belt). Their maximum age of deposition is based on the youngest detrital zircon population and minimum age of deposition based on stratigraphic, paleontological, and cross-cutting intrusive relationships. The determined range of depositional ages are: Martinon between $602 \pm 8$ (youngest zircons) and $546 \pm 2 \mathrm{Ma}$ (age of cross-cutting intrusion); Flagg Cove between $574 \pm 7$ (youngest zircons) and $535 \pm 3 \mathrm{Ma}$ (age of cross-cutting intrusion); Matthews Lake between $539 \pm 5$ (youngest zircons) and $514 \pm 2 \mathrm{Ma}$ (age of overlying volcanic rocks); Ellsworth between $507 \pm 6$ (youngest zircons) and $504 \pm 3 \mathrm{Ma}$ (age of overlying volcanic rocks); Calais between $510 \pm 8$ (youngest zircons) and 479 $\pm 2 \mathrm{Ma}$ (graptolite zone); and Baskahegan Lake between $525 \pm 6$ (youngest zircons) and $488 \pm 2 \mathrm{Ma}$ (graptolite zone).

All samples are dominated by Neoproterozoic (Gondwanan) zircon populations. The Early Paleozoic Matthews Lake, Ellsworth, and Calais formations contain main population peaks at $539 \pm 5 \mathrm{Ma}, 545 \pm 4 \mathrm{Ma}$, and $556 \pm 7 \mathrm{Ma}$, respectively, consistent with derivation mainly from magmatic rocks of the Brookville, Grand Manan Island, and/or New River belts, previously dated at $\sim 553$ to $528 \mathrm{Ma}$. In contrast, the main peak in the Early Paleozoic Baskahegan Lake Formation is older at $585 \pm 5 \mathrm{Ma}$. The main peak in the Neoproterozoic to Early Cambrian Flagg Cove Formation is at $611 \pm 7 \mathrm{Ma}$ with a secondary peak at $574 \pm 7 \mathrm{Ma}$; the former was likely derived from locally exposed igneous units dated at 618 to $~ 611 \mathrm{Ma}$. The Neoproterozoic Martinon Formation exhibits dominant peaks at $674 \pm 8 \mathrm{Ma}$ and $635 \pm 4 \mathrm{Ma}$. Ganderian basement gneiss dated at $\sim 675 \mathrm{Ma}$ and intruded by plutonic rocks dated at $\sim 584 \mathrm{Ma}$ in the Hermitage Flexure of Newfoundland are possible sources for these older zircon components in the Martinon and Baskahegan Lake formations. Plutonic rocks in the New River belt dated at $\sim 629$ to 622 Ma may be the source of the younger component in the Martinon Formation.

The samples also contain a small number of Mesoproterozoic, Paleoproterozoic, and Archean zircon grains, the latter as old as $3.23 \mathrm{Ga}$. The presence of zircons in the range 1.07 to $1.61 \mathrm{Ga}$ is consistent with an origin along the periGondwanan margin of Amazonia rather than West Africa. The general similarity of zircon provenance for samples from New Brunswick and coastal Maine suggests that all the Ganderian belts were part of a single microcontinent rifted from the Amazonian craton.

The Grand Manan Island and New River belts both record two distinct periods of Neoproterozoic arc magmatism ( $\sim 629$ to $\sim 611 \mathrm{Ma}$ and at $\sim 553$ to $\sim 535 \mathrm{Ma}$ ) whereas the Brookville belt experienced only a single period of arc magmatism lasting from $\sim 553$ to $\sim 528 \mathrm{Ma}$. These differences are attributed to migration of the younger period of arc magmatism further inboard into Ganderia due to shallowing of the subduction zone. A Penobscot rifted arc system is
\end{abstract}


recorded in the New River and Ellsworth belts from $\sim 514$ to $~ 502 \mathrm{Ma}$, following migration of Ganderia into the widening Iapetus Ocean. The progressively younger depositional ages of the quartzose sandstone sequences of the Brookvlle belt (Martinon Formation), Grand Manan Island belt (Flagg Cove Formation) and New River belt (Matthews Lake Formation) can be attributed to these episodic periods of quiescence and arc activity along the convergent margin of Ganderia. Subsequent rifting of the Early Ordovician Meductic-Popelogan arc along a segment of the Ganderian margin led to the development of the Middle Ordovician Tetagouche back-arc volcanic activity in the Miramichi belt of central and northern New Brunswick.

\section{RÉSUMÉ}

On a déterminé par datation sur zircon détritique les âges d'échantillons de conglomérat et de grès provenant de six ceintures délimitées par des failles au Nouveau-Brunswick et sur la côte du Maine. Les formations échantillonnées comprenaient Martinon (ceinture de Brookville), Flagg Cove (ceinture de l'île Grand Manan), Matthews Lake (ceinture de New River), Ellsworth (ceinture d'Ellsworth), Calais (ceinture de St. Croix) et Baskahegan Lake (ceinture de Miramichi). Le moment maximal de leur sédimentation est basé sur la population de zircons détritiques la plus récente et le moment minimal, sur les liens stratigraphiques et paléontologiques ainsi que sur les intrusions transversales. L'éventail défini des périodes de sédimentation s'établit comme suit : Martinon, entre $602 \pm 8$ (zircons les plus récents) et $546 \pm 2 \mathrm{Ma}$ (âge de l'intrusion transversale); Flagg Cove, entre $574 \pm 7$ (zircons les plus récents) et $535 \pm 3 \mathrm{Ma}$ (âge de l'intrusion transversale); Matthews Lake, entre $539 \pm 5$ (zircons les plus récents) et $514 \pm 2 \mathrm{Ma}$ (âge des roches volcaniques sus-jacentes); Ellsworth, entre $507 \pm 6$ (zircons les plus récents) et $504 \pm 3 \mathrm{Ma}$ (âge des roches volcaniques sus-jacentes); Calais, entre $510 \pm 8$ (zircons les plus récents) et $479 \pm 2 \mathrm{Ma}$ (zone de graptolites); et Baskahegan Lake, entre $525 \pm 6$ (zircons les plus récents) et $488 \pm 2 \mathrm{Ma}$ (zone de graptolites).

Tous les échantillons présentent une prédominance de populations de zircons néoprotérozoïques (gondwaniennes). Les formations du Paléozoïque précoce de Matthews Lake, d'Ellsworth et de Calais présentent les principaux sommets des populations à $539 \pm 5 \mathrm{Ma}, 545 \pm 4 \mathrm{Ma}$ et $556 \pm 7 \mathrm{Ma}$, respectivement, ce qui correspond à une origine essentiellement en provenance des roches magmatiques des ceintures de Brookville, de l'île Grand Manan ou de New River, précédemment situées à environ 553 à 528 Ma. À l'opposé, le principal sommet de la Formation du Paléozoïque précoce de Baskahegan Lake remonte à plus de $585 \pm 5 \mathrm{Ma}$. Le principal sommet de la Formation du Néoprotérozoïque au Cambrien précoce de Flagg Cove se situe à $611 \pm 7 \mathrm{Ma}$, et un sommet secondaire, à $574 \pm 7 \mathrm{Ma}$; le premier provient vraisemblablement d'unités ignées affleurant localement et datées à environ 618 à $611 \mathrm{Ma}$. Les sommets prédominants à l'intérieur de la Formation du Néoprotérozoïque de Martinon remontent à $674 \pm 8$ Ma et $635 \pm 4 \mathrm{Ma}$. Le gneiss gandérien du socle, situé à environ $675 \mathrm{Ma}$ et pénétré par des roches plutoniques d'un âge estimatif de 584 Ma dans la charnière d'Hermitage à Terre-Neuve, constitue la source possible de ces composantes de zircons plus âgées à l'intérieur des formations de Martinon et de Baskahegan Lake. Les roches plutoniques de la ceinture de New River, datées à environ 629 à $622 \mathrm{Ma}$, pourraient représenter la source de la composante plus récente à l'intérieur de la Formation de Martinon.

Les échantillons renferment en outre un nombre modeste de grains de zircons du Mésoprotérozoïque, du Paléoprotérozoïque et de l'Archéen, les derniers ayant jusqu'à 3,23 Ga. La présence de zircons de l'ordre de 1,07 à 1,61 milliard d'années est compatible avec une origine du long de la marge périgondwanienne de l'Amazonie plutôt que de l'Afrique occidentale. La similarité générale de la provenance des zircons des échantillons du Nouveau-Brunswick et du littoral du Maine permet de supposer que toutes les ceintures gandériennes faisaient partie d'un microcontinent unique s'étant détaché du craton amazonien.

Les ceintures de l'île Grand Manan et de New River consignent toutes deux deux périodes distinctes de magmatisme de type arc du Néoprotérozoïque (vers 629 à 611 Ma ainsi que vers 553 à $535 \mathrm{Ma}$ ), tandis que la ceinture de Brookville a connu seulement une période de magmatisme d'arc ayant duré d'environ 553 à $528 \mathrm{Ma}$. Ces différences sont attribuées à une migration de la période plus récente du magmatisme d'arc plus à l'intérieur de Ganderia en raison de l'exhaussement de la zone de subduction. Un système à arc de divergence de Penobscot est enregistré dans les ceintures de New River et d'Ellsworth vers 514 à $502 \mathrm{Ma}$, à la suite de la migration de Ganderia dans l'océan grandissant Iapetus. Les époques de sédimentation progressivement plus récentes des séquences de grès quartzeux de la ceinture de Brookville (Formation de Martinon), de la ceinture de l'île Grand Manan (Formation de Flagg Cove) et de la ceinture de New River (Formation de Matthews Lake) peuvent être attribuées à ces périodes épisodiques de quiescence et d'activité d'arc le long de la marge convergente de Ganderia. Une distension subséquente de l'arc de l'Ordovicien précoce de Meductic-Popelogan le long d'un segment de la marge gandérienne a mené au développement de l'activité volcanique d'arrière-arc de l'Ordovicien moyen de Tetagouche à l'intérieur de la ceinture de Miramichi, dans le Centre et le Nord du Nouveau-Brunswick.

[Traduit par la redaction] 


\section{INTRODUCTION}

The nature and provenance of the Ganderian microcontinent is a contentious issue, but vital to understanding the tectonic evolution of the northern Appalachians during the Paleozoic. Most workers agree that Ganderia is a piece of Gondwana that rifted away during the Late Cambrian/Early Ordovician, based mainly on faunal and paleomagnetic data (van Staal et al. 1996, 1998; van Staal 2007). There also appears to be general agreement that collisions of peri-Gondwanan terranes (Ganderia, Avalonia, Meguma) with Laurentia were responsible for Paleozoic orogenesis along the eastern seaboard of New Brunswick and Maine. However, debate continues on the particular timing of these collisions and on which lithotectonic belts in coastal New Brunswick and Maine should be included in Ganderia versus Avalonia (Currie 1986; Nance 1987; van Staal and Fyffe 1991, 1995a; van Staal et al. 1996,1998; Barr and White 1996; Fyffe et al. 1999; Johnson 2001; Tucker et al. 2001; Barr et al. 2003a; Landing et al. 2008).

Based mainly on differences in their pre-Late Ordovician stratigraphy and magmatic history, several fault-bounded lithotectonic belts have been recognized in the northern Appalachians of Atlantic Canada and New England (Hibbard et al. 2006, 2007). Those in New Brunswick and coastal Maine are considered to have been situated along the southeastern, i.e. Gondwanan, margin of the Iapetus Ocean in the Early Paleozoic (Fig. 1), and include Caledonia, Brookville, New River, Ellsworth, Annidale, St. Croix, and Miramichi (Fyffe and Fricker 1987; Ruitenberg et al. 1993; van Staal and Fyffe 1995a; Barr and White 1996; Johnson and McLeod 1996; Shultz et al. 2008). In addition, Grand Manan Island is considered herein as a separate belt because of its isolation from, and uncertain relationship to rocks exposed on the New Brunswick mainland (Fig. 2). All but the Caledonia belt are herein included in Ganderia (Figs.1, 2), based in part on the common presence of lithologically similar, Late Neoproterozoic to Early Ordovician, predominantly continent-derived, quartzose sedimentary sequences; and/or Neoproterozoic volcanic and plutonic rocks characterized by negative $\varepsilon_{\mathrm{Nd}}$ signatures (Whalen et al. 1994, 1996a,b; van Staal et al. 1996; van Staal et al. 1998; Samson et al. 2000; Hibbard et al. 2006; Shultz et al. 2008) and non-depleted $\delta^{18} \mathrm{O}$-isotope signatures (Potter et al. 2008). The Caledonia belt is included in Avalonia on the basis of its distinctive Neoproterozoic volcanic and plutonic rocks with positive $\varepsilon_{\mathrm{Nd}}$ signatures indicative of derivation from juvenile crust (Samson et al. 2000), and depleted $\delta^{18} \mathrm{O}$-isotope signatures (Potter et al. 2008). Both Avalonia and Ganderia were amalgamated with the Laurentian margin of North America by subduction of various oceanic tracts and back-arc basins during the Late Ordovician and Silurian (van Staal and Fyffe 1995a,b; Barr and White 1996; van Staal et al.1998, 2008; Barr et al. 2002; Wintsch et al. 2007).

The present boundaries of the lithotectonic belts in coastal New Brunswick and Maine are obscured by Late Ordovician (Ashgillian) and younger cover rocks and by Silurian - Devonian plutons, so that deciphering their original relationships is commonly difficult. Whereas the boundaries of many of these belts are currently defined by transcurrent faults known to have been active during Silurian and Devonian orogenesis and subsequent development of the Maritimes Basin (Mann et al. 1983; Stewart et al. 1995; Lin et al. 1994; van Staal and de Roo 1996; Tucker et al. 2001), their distinctive stratigraphies and magmatic histories (Fig. 3) are at least in part products of much older Iapetan and pre-Iapetan tectonic regimes. It is

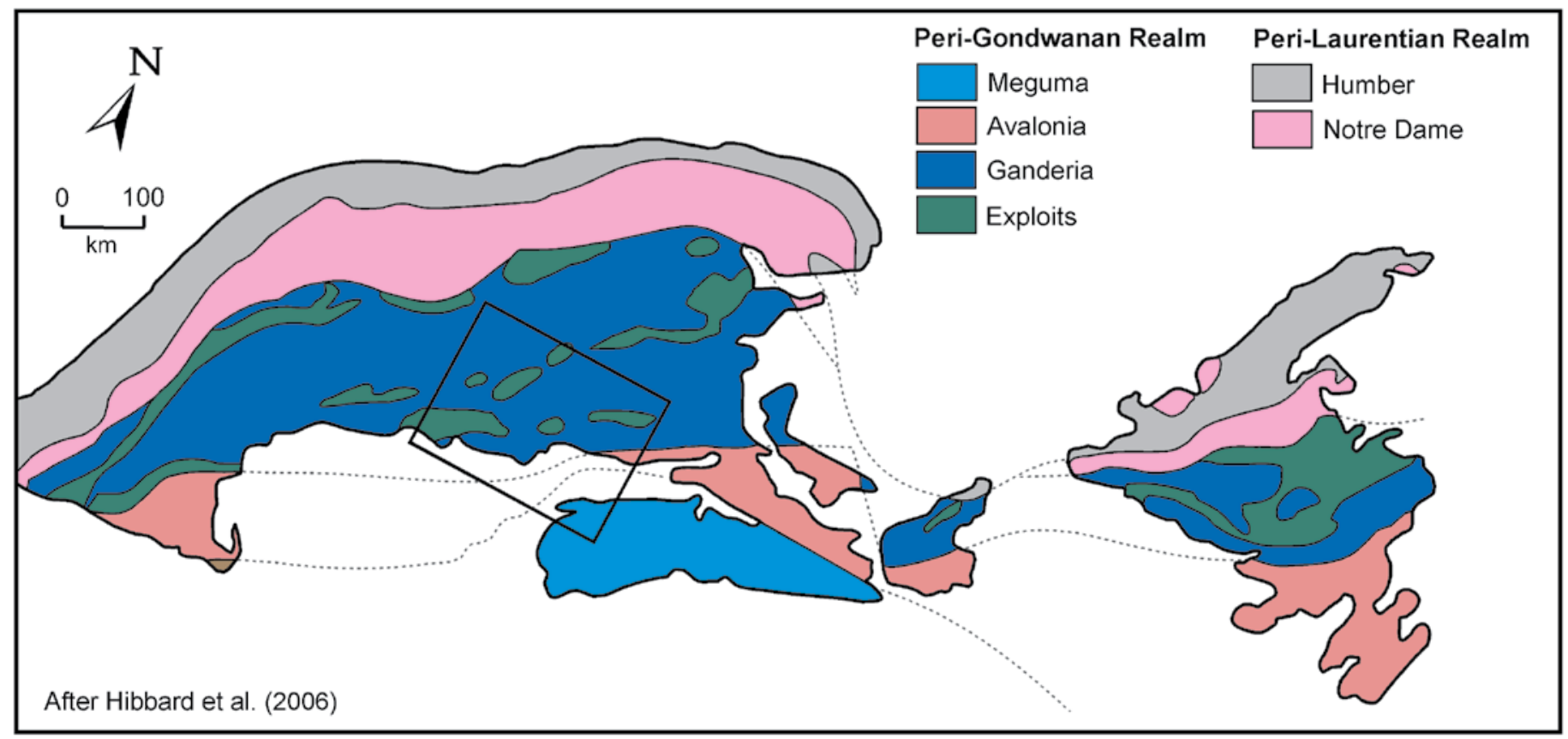

Fig. 1. Lithotectonic divisions of the northern Appalachian orogen (after Hibbard et al. 2006). The area shown in Fig. 2 is outlined. 


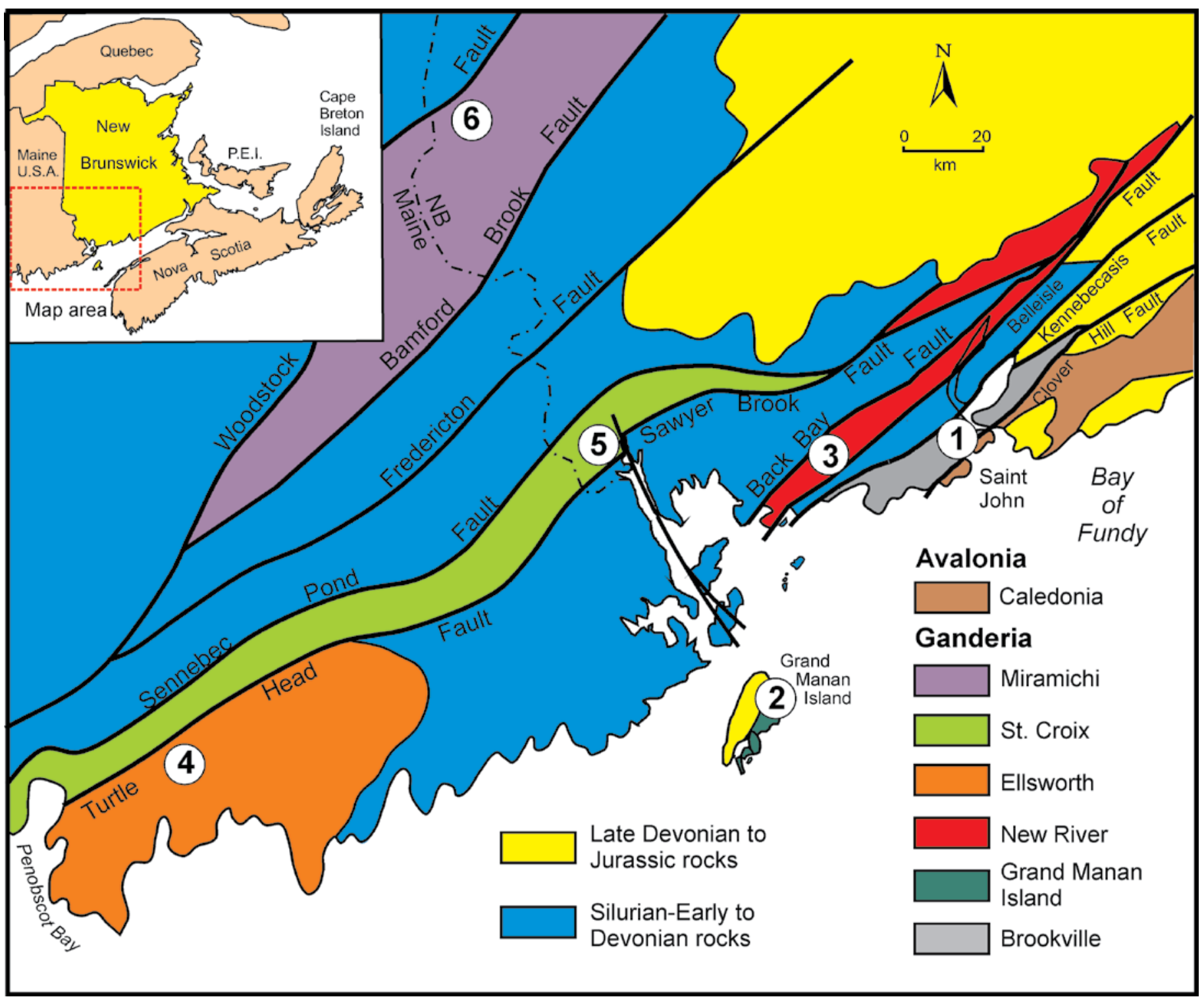

Fig. 2. Simplified geology and tectonostratigraphic belts in southern New Brunswick and adjacent Maine. Sample locations are shown by circled numbers.

argued below that many of the belts presently defined in New Brunswick and Maine should be viewed as dismembered and dispersed fragments of older continental-margin and oceanicarc systems. As demonstrated, for example, by Wintsch et al. (2007), detrital zircon studies in this part of the Appalachians can provide a test as to whether juxtaposed fault slices have been derived from similar or different source areas.

The purpose of this paper is to present results from analyses of detrital zircon from lithologically similar, Neoproterozoic to Early Ordovician, quartzose sedimentary rocks in the Brookville, Grand Manan Island, New River, Ellsworth, St. Croix, and Miramichi belts to test their proposed affinity to Ganderia. If the zircon populations are essentially the same, it would strengthen the assumptions that they all form part of Ganderia. If not, these data could provide supporting evidence for the existence of other Gondwanan terranes. The data provide information on both provenance and on the maximum age of deposition of these mainly unfossiliferous units. These results are integrated with known stratigraphic relationships, magmatic history, and geochemical characteristics to suggest possible paleotectonic linkages among the various fault-bounded lithotectonic belts in New Brunswick and coastal Maine.

\section{GANDERIAN BELTS}

Geological features of the six sampled pre-Late Ordovician Ganderian belts are summarized briefly here to provide context for the individual detrital zircon sample locations (Figs. $2,3,4)$. 

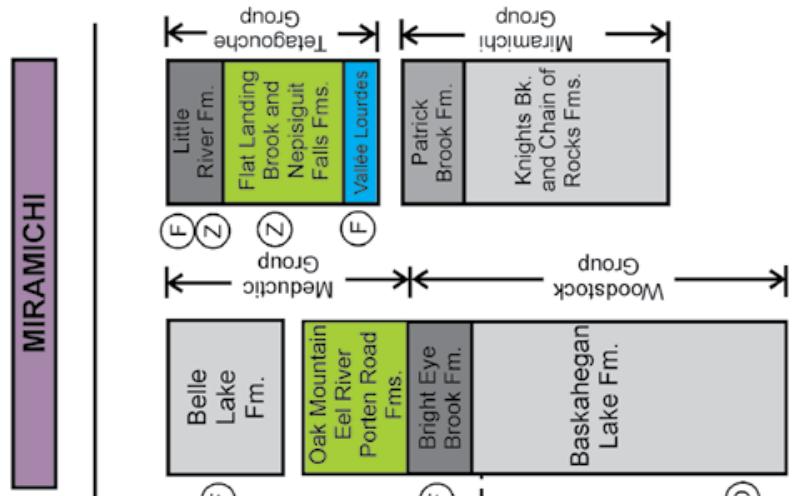

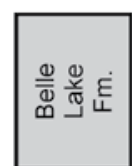

(4)

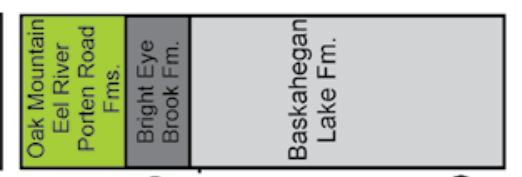

(4)

()
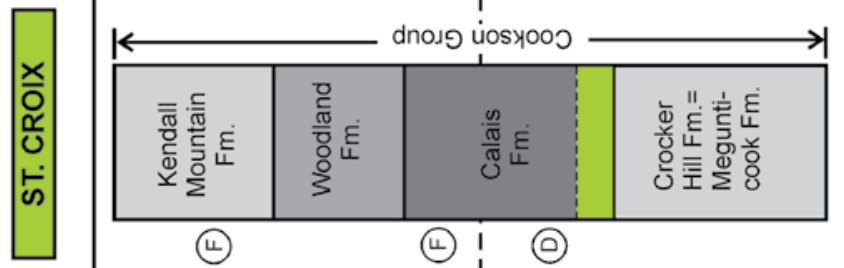

(4)

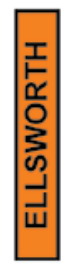

(4)

○)
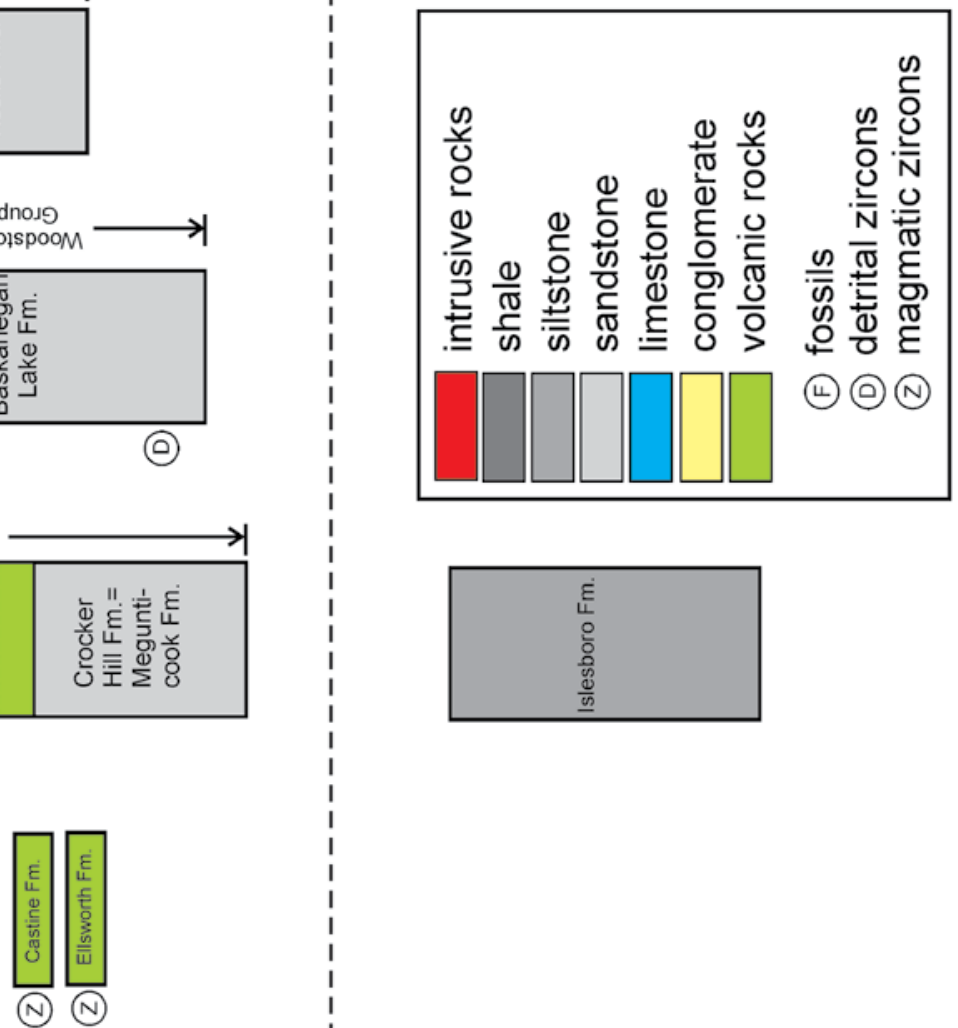

苟

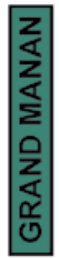

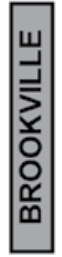
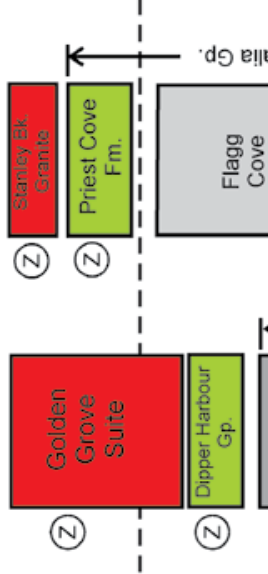

(N) 1
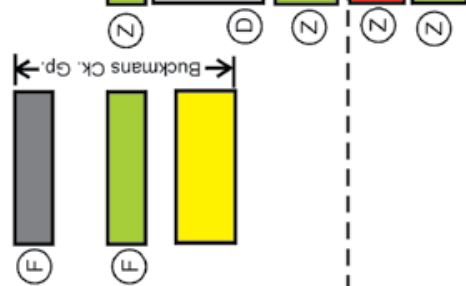

en!eiseว

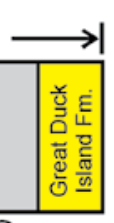

()

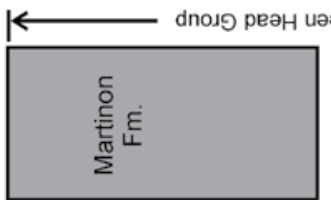

()
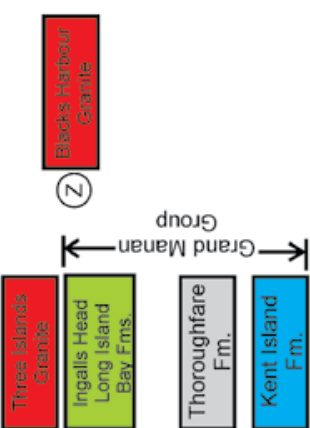

(ㅅ) ()

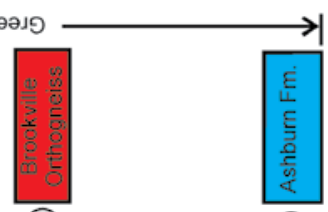

()

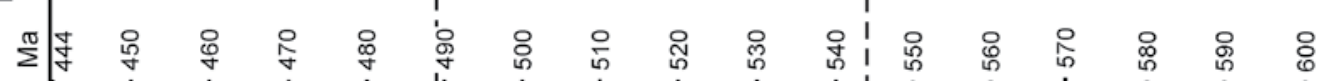

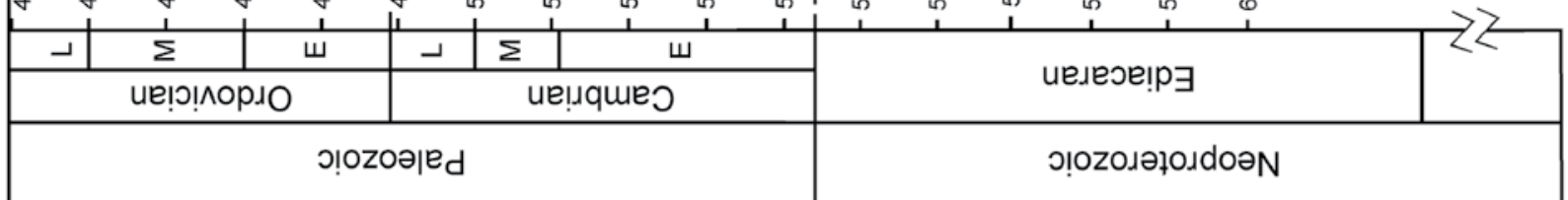



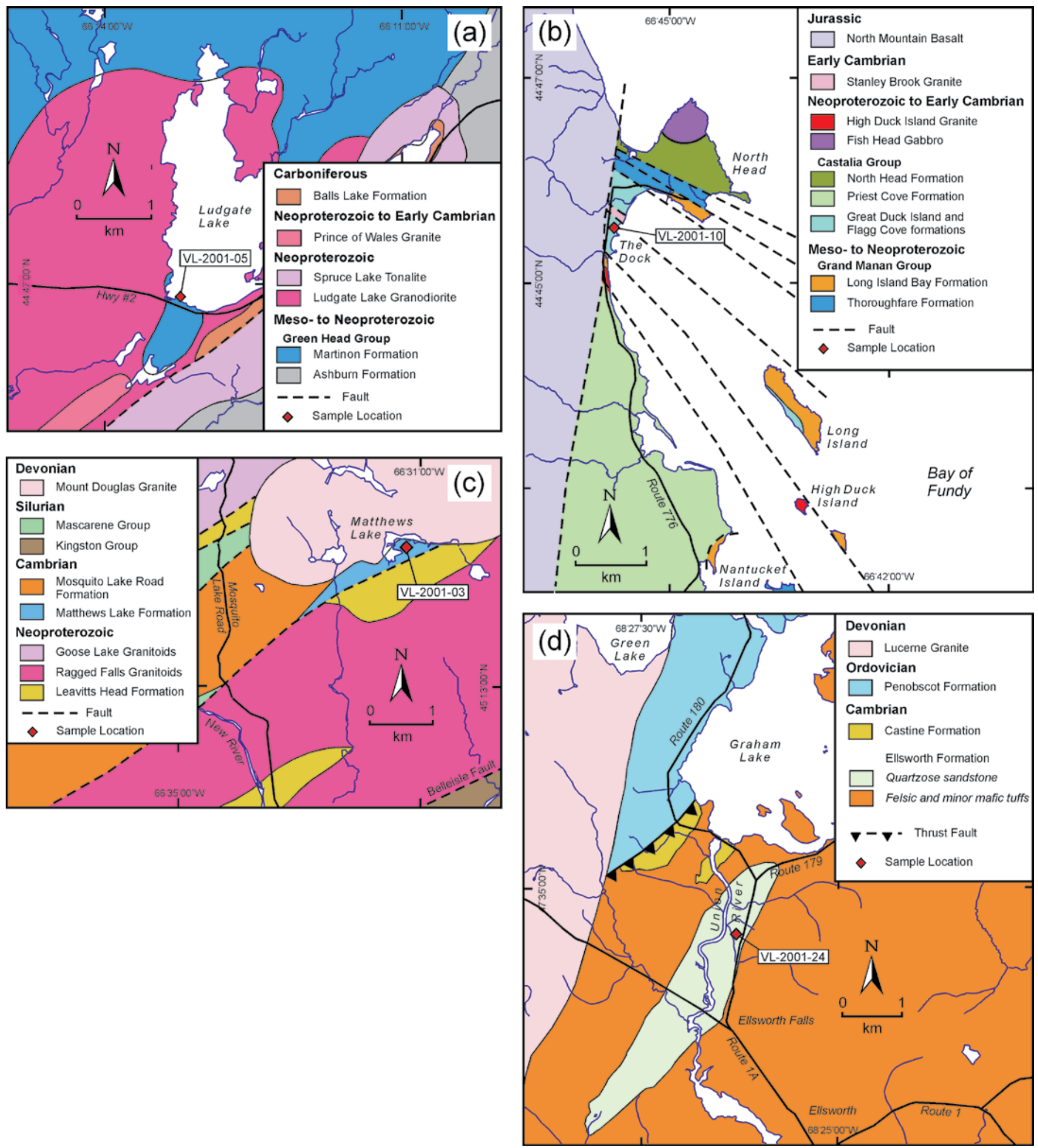

Fig. 4. Simplified geological maps showing location of analysed samples: (a) Martinon Formation (Brookville belt), modified from White et al. (2002); (b) Flagg Cove Formation (Grand Manan Island), modified from Fyffe and Grant (2005); (c) Matthews Lake Formation (New River belt), modified from Johnson and McLeod (1996); and (d) Ellsworth Formation (Ellsworth belt), modified from Pollock (2008). [Continued next page.] 

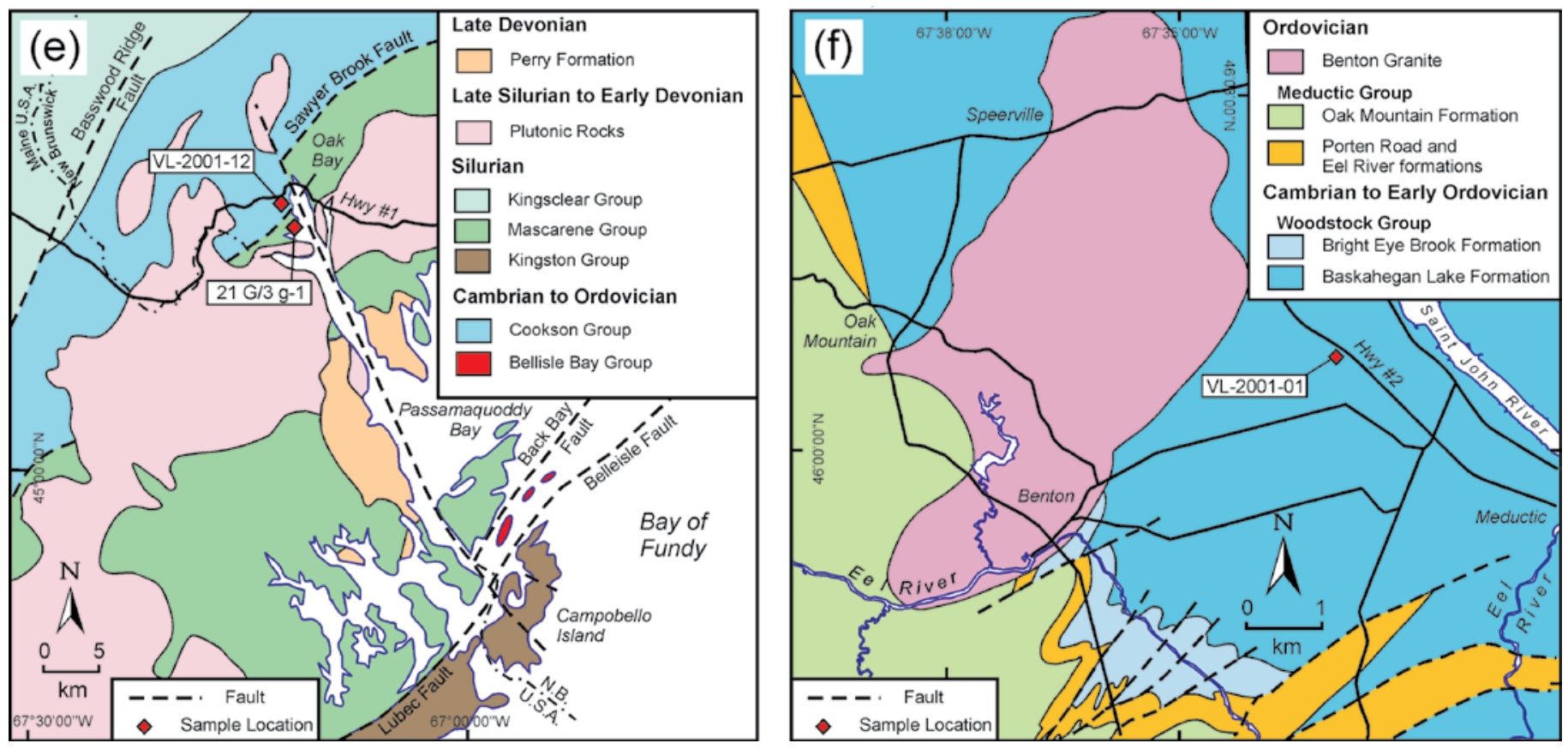

Fig. 4. [Continued from previous page.] Simplified geological maps showing location of analysed samples: (e) Calais and Oak Bay formations (St. Croix Belt), modified from Fyffe et al. (1999); and (f) Baskahegan Lake Formation (Miramichi belt), modified from Fyffe (2001).

\section{Brookville Belt}

Sedimentary and gneissic rocks of the Brookville belt (Fig. 4a) possibly range from Mesoproterozoic to Neoproterozoic and are intruded by Neoproterozoic to Early Cambrian plutons that largely possess calc-alkaline trends interpreted to represent continental margin magmatism (Eby and Currie 1996; White and Barr 1996; Currie and McNicoll 1999; White et al. 2002). The sedimentary rocks include stromatolitic marble and lesser quartzose sandstone of the Ashburn Formation; and siltstone, quartzose sandstone, quartzite-pebble conglomerate, and marble breccia of the overlying Martinon Formation that together comprise the Green Head Group (Alcock 1938; Leavitt 1963; Hofmann 1974). The Green Head Group is in sheared contact with the Brookville Gneiss, a unit of paragneiss and orthogneiss, the latter dated at $\sim 605 \mathrm{Ma}$ (Bevier et al. 1990; Dallmeyer et al. 1990). The Golden Grove Plutonic Suite and minor volcanic rocks of the Dipper Harbour Formation in the Brookville belt have yielded ages of $\sim 53$ to $\sim 528 \mathrm{Ma}$. (Currie and McNicoll 1999; White et al. 2002; Barr et al. 2003a). Sample VL-2001-05 was collected from a quartzite-pebble conglomerate bed in the Martinon Formation at Ludgate Lake (Fig. 4a) to provide information on provenance and to constrain the depositional age of the formation.

The Brookville belt is interpreted to form basement to Ganderia based on the presence of late Mesoproterozoic cobbles with negative $\varepsilon_{\mathrm{Nd}}$ signatures in Early Ordovician limestone of the Miramichi belt (van Staal et al. 1996), and the relationship of equivalent rocks in the Bras d'Or terrane of Cape Breton Island and Newfoundland to Paleozoic Ganderian units (White and Barr 1996; Barr et al. 1998). The Clover Hill Fault marks the boundary between the Ganderian Brookville belt and the Avalonian Caledonia belt (Fig. 2).

\section{Grand Manan Island Belt}

The oldest Neoproterozoic rocks on Grand Manan and nearby islands (Figs. 2, 3, 4b) include the Kent Island, The Thoroughfare, Ingalls Head, and Long Island Bay formations of the Grand Manan Group (Fyffe and Grant 2001, 2005; Barr et al. 2003b; Black et al. 2004). Carbonate rocks of the Kent Island Formation are known only from marble inclusions in the $\sim 611 \mathrm{Ma}$ Three Islands Granite exposed on Kent Island off the southern coast of Grand Manan (Miller et al. 2007). The Thoroughfare Formation is characterized by the presence of very thick-bedded, white quartzite interstratified with carbonaceous black shale. The marble and quartzite have been correlated with the Ashburn Formation in the Brookville belt (Alcock 1948). Although Grand Manan Island lacks the abundant $~ 553$ to 528 Ma plutons that characterize the Brookville belt, it does include small granitic plutons with ages of $\sim 547$ and $\sim 535 \mathrm{Ma}$ (see below), consistent with such a correlation (Fig. 3).

Felsic and mafic flows, and intermediate tuff and breccia (locally interbedded with iron-rich green to maroon volcaniclastic siltstone) of the Ingalls Head Formation on the southern part of Grand Manan Island has been dated at $618 \mathrm{Ma}$ (Barr et al. 2003b; Black et al. 2004; Miller et al. 2007). A sequence of plagioclase-phyric basaltic mafic flows, felsic lithic tuff, and green and maroon siltstone, exposed north of Castalia, and on Long, High Duck, Low Duck, and Great Duck islands (Fig. 4b), considered by Fyffe and Grant $(2001,2005)$ to correlate 
with the Ingalls Head Formation, has been referred to as the Long Island Bay Formation by Barr et al. (2003b), Black et al. (2004), and Miller et al. (2007). Maroon siltstone of the Long Island Bay Formation exposed on the shore north of Castalia has been intruded by a fine-grained, felsic dyke (referred to as the High Duck Island Granite after exposures offshore) dated at $~ 547 \mathrm{Ma}$ (Barr et al. 2003b; Black et al. 2004; Miller et al. 2007). Geochemical data suggest a suprasubduction-zone origin for the volcanic rocks of the Ingalls Head and Long Island Bay formations (Pe-Piper and Wolde 2000; Black et al. 2004).

Younger Neoproterozoic to Cambrian strata of the Castalia Group are divided into four formations (Figs. 3, 4b); two sedimentary (Great Duck Island and Flagg Cove), and two that are volcanic-rich (Priest Cove and North Head). Contacts of the Castalia Group with the older volcanic rocks of the Grand Manan Group are generally faulted but an unconformity is preserved on Long Island, where pebble to cobble conglomerate of the Great Duck Island Formation contains volcanic clasts derived from an immediately underlying plagioclasephyric mafic flow of the Long Island Bay Formation. A similar conglomerate, exposed at The Dock on Grand Manan Island, contains abundant quartzite clasts likely derived from The Thoroughfare Formation of the Grand Manan Group (Fyffe and Grant 2001).

The Flagg Cove Formation comprises thin- to medium-bedded, graded, quartzose sandstone, shale, and minor quartzite-pebble conglomerate. It contains the trace fossil Planolites and is intruded by the Stanley Brook Granite dated at 535 Ma (Fyffe and Grant 2001, 2005; Miller et al. 2007). A sample of quartzose sandstone (VL-2001-10) from the Flagg Cove Formation was collected approximately $250 \mathrm{~m}$ north of The Dock (Fig. 4b) to provide information on provenance and to further constrain its depositional age.

The Priest Cove Formation, the areally most extensive unit on Grand Manan Island, comprises mainly mafic tuff and volcaniclastic sandstone. A felsic lithic-crystal tuff, interbedded with the mafic tuff, has been dated at $\sim 539 \mathrm{Ma}$ (Black et al. 2004; Miller et al. 2007), suggesting a cogenetic relationship with the Stanley Brook Granite. Such a cogenetic relationship would indicate that the Priest Cove volcanic rocks overlie the sedimentary rocks of the Flagg Cove Formation. Massive mafic flows and breccia of the North Head Formation (Fig. 4b) are considered to be proximal facies of the Priest Cove Formation by Fyffe and Grant $(2001,2005)$. The Early Cambrian age of the Priest Cove Formation is identical to that of volcanic rocks of the Simpsons Island Formation in the New River belt (see below) on the New Brunswick mainland (Fig. 4b,c).

\section{New River Belt}

Neoproterozoic volcanic and plutonic rocks of the New River belt extend from the New River area in southwestern New Brunswick to the Belleisle Bay area in the northeast (Fig. $2,3,4 \mathrm{c})$. Plutonic rocks along the southeastern flank of the New River belt include the Lingley and Blacks Harbour gran- ites, dated respectively at $\sim 629 \mathrm{Ma}$ (Currie and McNicoll 1999) and $622 \mathrm{Ma}$ (Barr et al . 2003a). Felsic volcanic rocks of the Leavitts Head Formation dated at $549 \pm 6 \mathrm{Ma}$ (McLeod et al. 2003), and intrusive rocks of the Ragged Falls Granite dated at $\sim 553 \mathrm{Ma}$ (Currie and Hunt 1991; Johnson and McLeod 1996; Johnson 2001; McLeod et al. 2003) in the New River area lie along the northwestern flank of the New River belt.

Interbedded shallow-water volcanic and sedimentary rocks of the Cambrian Buckmans Creek "group" are faulted against the Blacks Harbour Granite along the Belleisle fault, which defines the southeastern boundary of the New River belt (Fig. 2). The "group" consists of a lower section of conglomerate and quartzose sandstone, a middle section of basaltic volcanic rocks and pyroclastic rocks, and an upper section of pyritiferous black shale (Greenough et al. 1985; Johnson 2001). Early to Middle Cambrian trilobites are found in thin nodular limestone beds near the base of the middle section (Helmstaedt 1968; Landing et al. 2008). The basaltic volcanic rocks have an evolved, tholeiitic geochemical signature suggesting an intraplate continental origin (Greenough et al. 1985).

Felsic and mafic volcanic rocks and arkosic sandstone of the Simpsons Island Formation (Belleisle Bay Group) lie along the faulted northwestern flank of the Blacks Harbour Granite marked by the Letang Harbour fault (McLeod 1995; Johnson and McLeod 1996; McLeod et al. 2001; Johnson 2001; Johnson and Barr 2004). A felsic flow from the Simpsons Island Formation has been dated at $539 \mathrm{Ma}$, i.e. early Early Cambrian (Barr et al. 2003a). Deeper water Cambrian sedimentary and volcanic sequences along the northwestern flank of the Ragged Falls Granite are included in the Matthews Lake and Mosquito Lake Road formations (Fig. 4c). The Mosquito Lake Road Formation contains iron-rich volcaniclastic sandstone interbedded with felsic flows and tuff dated at 514 Ma, indicative of a late Early Cambrian age (Johnson and McLeod 1996; Ruitenberg et al. 1993; McLeod et al. 2003). The close proximity of these deeper water Cambrian facies to essentially coeval shallow-water facies of the Buckmans Creek "group" suggests that considerable structural telescoping has taken place along the Letang Harbour fault within the New River belt (Johnson 2001; Johnson and Barr 2004). Geochemical data on the mafic volcanic rocks of the Simpsons Island and Mosquito Lake Road formations suggest both were produced in suprasubduction-zone setting (Johnson and McLeod 1996).

Quartzose sandstone and intraformational quartzite-pebble conglomerate of the Matthews Lake Formation were originally correlated with a polymictic conglomeratic sequence that contains felsic volcanic clasts derived from the immediately underlying Mosquito Lake Road Formation (Johnson and McLeod, 1996). However, the textural and mineralogical maturity of the quartz-rich sandstone and conglomerate in the type section near Matthews Lake suggests that the Matthews Lake Formation may lie beneath the Mosquito Lake Road Formation. The contact between the sedimentary rocks of the Matthews Lake Formation and New River basement rocks in the Matthews Lake area is not exposed. Sample VL-2001-03 
was collected from quartzose sandstone at the type section (Fig. 4c) to provide information on provenance and to constrain the depositional age of the Matthews Lake Formation.

\section{Annidale Belt}

Cambrian volcanic and sedimentary rocks also occur to the northeast in the Annidale belt of the Belleisle Bay area (Fig. 2). The Annidale Group comprises a fault-imbricated assemblage of mafic pillow basalt and hyaloclastic tuff, rhyolite flows and domes (dated at $493 \mathrm{Ma}$ ), and sandstone and black shale (McLeod et al. 1992, 1994; Ruitenberg et al. 1993). Ordovician rhyolite dome complexes dated at $\sim 478$ to $\sim 472$ Ma intrude the Annidale Group (G. Dunning, unpublished data). Tectonic interleaving of the Annidale Group and its juxtaposition with Neoproterozoic New River basement to the southeast occurred prior to $476 \mathrm{Ma}$, the age of the Stewarton gabbro pluton(G. Dunning, unpublished data). Basalt to basaltic andesite predominant in the Annidale Group and possess tholeiitic geochemical characteristics consistent with a suprasubduction-zone setting. Less common basaltic volcanic rocks associated with plagiogranite intrusions within a narrow thrust sliver display a N-MORB-like geochemical pattern (McLeod et al. 1994).

\section{Ellsworth Belt}

The lithological characteristics of the Middle Cambrian volcanic sequences in the Ellsworth belt of the Penobscot Bay area of coastal Maine (Stewart and Wones 1974; Stewart et al. 1995) are generally similar to both those of the somewhat older Mosquito Lake Road Formation of the New River belt and somewhat younger Annidale Group of the Annidale belt in New Brunswick (Figs. 2, 3, 4d). Felsic tuff of the Ellsworth Formation and a felsic dome in the Castine Formation have been dated at $\sim 509$ and $\sim 504 \mathrm{Ma}$, respectively (Ruitenberg $e t$ al. 1993; Schultz et al. 2008). Pillowed to massive mafic volcanic rocks in the Ellsworth and Castine formations possess geochemical characteristics similar to depleted to evolved, mid-oceanic-ridge tholeiitic basalts (Schultz et al. 2008).

The exposed contact between Ellsworth Formation of the Ellsworth belt and Ordovician Penobscot Formation of the St. Croix belt in Maine is marked by the Turtle Head fault (Stewart and Wones 1974; Stewart et al. 1995). Sample VL-2001-24 was collected from quartzose sandstone (VL-2001-24) that is infolded with tuffaceous rocks of the Ellsworth Formation at Ellsworth Falls in coastal Maine (Fig. 4d) to compare its provenance with that of broadly correlative rocks in the Mosquito Lake Road Formation in the New River belt of New Brunswick.

\section{St. Croix Belt}

The St. Croix belt in New Brunswick and adjacent Maine is characterized by the Cookson Group (Ruitenberg 1967), a thick sequence of clastic sandstone and shale ranging in age from Late Cambrian to Middle Ordovician (Figs. 2, 3, 4e) The Cookson Group is divided from the base upward into the Crocker Hill, Calais, Woodland, and Kendall Mountain formations (Ludman 1987, 1991; Fyffe and Riva 1990). The Crocker Hill Formation is characterized by thick-bedded quartzose sandstone containing pods of pink garnet (coticules). Its stratigraphic position and garnetiferous nature strongly suggest a correlation with the Megunticook Formation in the Penobscot Bay area of Maine (Tucker et al. 2001). The Calais Formation is mostly carbonaceous black shale containing minor thin beds of silty sandstone; a pillow basalt unit occurs just above the contact with the Crocker Hill Formation. The geochemical characteristics of the pillow basalt are similar to evolved, mid-oceanic-ridge tholeiites (Fyffe et al. 1988). Sample VL2001-12 was collected from a bed of sandstone in the Calais Formation at Oak Bay about $250 \mathrm{~m}$ south of the tombolo opposite Cookson Island (Fig. 4e) in order to compare its provenance with samples from the New River and Miramichi belts.

Graptolites found on Cookson Island in Oak Bay indicate that the Calais Formation is as young as Tremadocian (Early Ordovician) (Fyffe and Riva, 1990). A U-Pb date of $~ 503 \mathrm{Ma}$ on a tuff bed interbedded with black shale of the equivalent Penobscot Formation in Maine suggests that age of the Calais Formation it extends down into the Middle Cambrian(Tucker et al., 2001). The Woodland Formation comprises thin- to medium-bedded, convolute-laminated, feldspathic sandstone interbedded with siltstone and shale. The Kendall Mountain Formation comprises thick-bedded, quartzose sandstone interbedded with carbonaceous black shale, and minor quartzpebble conglomerate. Graptolites from the shale are indicative of Caradocian (Late Ordovician) age (Fyffe and Riva, 1990).

Basement to the St. Croix belt is not exposed in New Brunswick. However, in coastal Maine a fault sliver of marble, quartzite, and amphibolite (Seven Hundred Acre Island Formation) cross-cut by an $\sim 670 \mathrm{Ma}$ pegmatite is juxtaposed against the St. Croix belt along the Turtle Head fault. Greenschist-facies siltstone, limestone, and quartzite-pebble conglomerate of the Islesboro Formation are interpreted to represent a platformal sedimentary sequence that unconformably overlies the amphibolite-facies basement rocks of the Seven Hundred Acre Island Formation, although the actual contact is not exposed (Stewart et al. 2001). In a paleogeographic reconstruction of fault-bounded slices on the adjacent mainland, Tucker et al. (2001) interpreted a sequence of limestone and conglomerate, equivalent to the Islesboro Formation, on Islesboro Island to be stratigraphically overlain by the Megunticook Formation. They also suggested that the Islesboro sequence has lithologic similarities to the Ashburn and Martinon formations in the Brookville belt. However, it should be mentioned that neither the Islesboro Formation nor Seven Hundred Acre Island Formation is intruded by the Neoproterozoic plutons that characterize the Brookville belt in New Brunswick (Fig. 3). 


\section{Miramichi Belt}

The Miramachi belt in the Bathurst area of northeastern New Brunswick (Fig. 3) is characterized by a Cambrian to Early Ordovician quartzose sedimentary sequence (Miramichi Group) and overlying Middle to Late Ordovician volcanic rocks of the Tetagouche Group (van Staal and Fyffe 1991, 1995a,1995b; van Staal et al. 1992, 1996, 2003; Fyffe et al. 1997). The Miramichi Group is divided into a lower unit of thickbedded quartzose sandstone (Chain of Rocks Formation), a middle unit of medium-bedded quartzose sandstone and shale (Knights Brook Formation), and an upper unit of medium-bedded, felspathic sandstone and shale (Patrick Brook Formation).

The base of the overlying Tetagouche Group is exposed near Tetagouche Falls on the Tetagouche River, where a thin unit of conglomerate, and calcareous sandstone and siltstone (Vallée Lourdes Formation) lies unconformably on sandstone beds of the Patrick Brook Formation. The calcareous siltstone on the Tetagouche River and correlative limestone beds in central New Brunswick contain Arenigian brachiopods of the Celtic biogeographic province (Fyffe 1976; Neuman 1984; Fyffe et al. 1997; Poole and Neuman 2003). The corresponding unconformity between the Cambrian Grand Pitch Formation and Early Ordovician Shin Pond Formation in adjacent Maine defines the Penobscot disturbance of the northeastern Appalachian orogen (Neuman 1964).

Volcanic rocks overlying the Vallée Lourdes Formation are divided into a lower unit of quartz-feldspar crystal tuff and iron formation (Nepisiguit Falls Formation), a middle unit of aphyric to sparsely feldspar-phyric felsic flows (Flat Landing Brook Formation), and an upper unit of mafic volcanic rocks interbedded with ferromanganiferous cherty siltstone and black shale (Little River Formation). The bimodal volcanic rocks of the Tetagouche Group are considered on the basis of their geochemical composition to have been generated in an intra-arc rift to back-arc basin transitional setting (van Staal 1987; van Staal et al. 1991, 2008; van Staal and Fyffe 1995a).

The Miramichi belt near Woodstock in west-central New Brunswick (Figs. 2, 3, 4f) is underlain by quartz-rich sedimentary and volcanic sequences referred to respectively as the Woodstock and Meductic groups (Fyffe 2001). The Woodstock Group includes quartzose sandstone and shale of the Baskahegan Lake Formation and conformably overlying carbonaceous black shale of the Bright Eye Brook Formation. Trace fossils recovered near Woodstock suggest that the Baskahegan Lake Formation may be as young as Early Ordovician (Pickerill and Fyffe 1999). Graptolites from the Bright Eye Brook Formation are indicative of an Early Ordovician (Tremadocian-early Arenigian) age (Fyffe et al. 1983). Sample VL-2001-1 was collected from a quartzose sandstone bed in the Baskahegan Lake Formation along Rte. 2 north of Meductic (Fig. 4f) in order to compare its provenance with that of the Miramichi Group, and with samples from the St. Croix, New River, and Ellsworth belts.

The conformably overlying Meductic Group is divided into the Porten Road Formation (felsic volcanic flows and tuff), Eel
River Formation (intermediate tuff and volcaniclastic rocks), Oak Mountain Formation (mafic volcanic flows and tuff), and Belle Lake Formation (felspathic sandstone and shale). Graptolites from the Belle Lake Formation are indicative of an early Caradocian (early Late Ordovician) age (Fyffe et al. 1983). The Benton pluton, which is comagmatic with the volcanic rocks of the Meductic Group, has been dated at 479 $\mathrm{Ma}$ (Whalen et al. 1998), thus indicating that volcanic activity in the Woodstock area began prior to that of the Tetagouche Group (dated at $474 \mathrm{Ma}$ to $457 \mathrm{Ma}$ ) in the Bathurst area. The Meductic volcanic rocks possess geochemical characteristics consistent with a suprasubduction-zone setting, and therefore, have been interpreted to represent a volcanic arc that developed just prior to opening of the Tetagouche back-arc basin (van Staal and Fyffe 1995b; Dostal 1989; Fyffe 2001).

\section{LATE ORDOVICIAN TO SILURIAN COVER ROCKS}

Cover rocks of predominately Silurian age generally are in faulted contact with, but locally unconformably overlie, the Neoproterozoic to Middle Ordovician belts described above. A belt of Early Silurian mainly felsic volcanic rocks of the Kingston Group and related plutons, bounded by the Kennebecasis and Lubec-Belleisle faults (Fig. 2), separates the Brookville belt from the New River belt (McLeod and Rast 1988; Eby and Currie 1993; McLeod et al. 2001; Barr et al. 2002). Fyffe et al. (1999) and Barr et al. (2002) proposed that the Kingston Group and related granitic plutons and younger mafic dykes represent an extensional volcanic arc formed during subduction of an oceanic tract separating Avalonia from Ganderia.

An extensive belt of Silurian volcanic and sedimentary rocks comprising the Mascarene Group (including the Oak Bay, Waweig, Eastport, and Letete formations) underlies the area between the Back Bay fault, which marks the northwestern boundary of the New River belt, and the Sawyer Brook fault, which marks the southeastern boundary of the St. Croix belt in New Brunswick (Johnson and McLeod 1996; Fyffe et al. 1999; Johnson 2001; Miller and Fyffe 2002). As such, the actual contact between the New River and St. Croix belts is hidden beneath the Silurian cover (Figs. 2, 4e). Strata of the Mascarene Group are also locally preserved on the southeastern side of the Back Bay fault and presumably lie unconformably on rocks of the New River belt. These cover rocks include Late Ordovician (Ashgillian) limestone of the Goss Point Formation and Early Silurian quartzose sandstone of the Back Bay Formation in the Letang Harbour area (Donohoe 1973; McLeod et al. 2001; Johnson and McLeod 1996). Silurian rocks correlative with the Mascarene Group also cover much of the Ellsworth belt in adjacent Maine (Gates 1969, 1989; Stewart et al. 1995). Such relationships led Fyffe and Fricker (1987) to propose that volcanic rocks correlative with the Ellsworth Formation extend from Maine into New Brunswick beneath Mascarene cover rocks.

Early Silurian feldspathic sandstone and shale of the 
Digdeguash Formation at the base of the Kingsclear Group lie disconformably on quartzose sandstone and shale of the Ordovician Kendall Mountain Formation along most of the northwestern margin of the St. Croix belt (Fyffe and Riva 1990, 2001; Fyffe et al. 1999). However along strike to the southwest, the contact is marked by the Basswood Ridge fault near the Maine border, by the South Princeton-Crawford fault across the border in Maine, and the Sennebec Pond fault in the Penobscot Bay area of coastal Maine (Ludman 1991; Stewart et al. 1995; Fyffe et al. 1999). The contact of the Silurian Kingsclear Group with the Miramichi belt to the northwest is marked by the Bamford Brook fault (Fyffe 1995).

Along the Sawyer Brook fault, Early Silurian conglomerate of the Oak Bay Formation at the base of the Mascarene Group lies with faulted angular unconformity on polydeformed Early Ordovician black shale of the Calais Formation along the southeastern boundary of the St. Croix belt. The conglomerate contains clasts of black shale obviously of local derivation but also contains an abundance of mafic and felsic igneous clasts of uncertain origin (Fyffe et al. 1999). A sample of this conglomerate $(21 \mathrm{G} / 3 \mathrm{~g}-1)$ was collected along the western shore of Oak Bay (Fig. 4e) to determine the provenance of the igneous clasts.

\section{ANALYTICAL METHODS}

SHRIMP II (Sensitive High Resolution Ion Microprobe) analyses were conducted at the Geological Survey of Canada using analytical and data reduction procedures described in detail by Stern (1997) and Stern and Amelin (2003) and briefly summarized here. Detrital zircons from the samples and fragments of the GSC laboratory zircon standard (z6266 zircon with ${ }^{206} \mathrm{~Pb} /{ }^{238} \mathrm{U}$ age $=559 \mathrm{Ma}$ ) were cast in an epoxy grain mounts (GSC mounts IP286, IP295, and IP296), polished with diamond compound to reveal the grain centres, and photographed in transmitted light (Fig. 5). The mount was evaporatively coated with $10 \mathrm{~nm}$ high purity $\mathrm{Au}$, and the internal features of the zircons were characterized with backscattered electrons (BSE) utilizing a scanning electron microscope (SEM). Representative SEM images of the grains with location of the SHRIMP spots marked are shown for each sample (Fig. 6). The numbers on the SEM images refer to the grain that was analysed and the age of the spot.

Analyses were conducted using an $\mathrm{O}^{-}$primary beam projected onto the zircons with an elliptical spot size ranging from about $15-20 \mu \mathrm{m}$ (in the longest dimension). The count rates of ten isotopes of $\mathrm{Zr}^{+}, \mathrm{U}^{+}, \mathrm{Th}^{+}$, and $\mathrm{Pb}^{+}$in zircon were sequentially measured with a single electron multiplier. Off-line data processing was accomplished using customized in-house software. The SHRIMP analytical data are presented in tables A1-A7. Common- $\mathrm{Pb}$ corrected ratios and ages are reported with $1 \sigma$ analytical errors, which incorporate external uncertainties of $1.10 \%$ (IP286), $1.00 \%$ (IP295) and 1.00\% (IP296) in calibrating the standard zircon (Stern and Amelin 2003). The ${ }^{206} \mathrm{~Pb} /{ }^{238} \mathrm{U}$ ages for analyses $<1000$ Ma have been corrected for common
$\mathrm{Pb}$ using both the 204- and 207-methods (Stern 1997), but generally no significant difference is apparent in the results (Appendix tables A1-A7).

The precision of single analyses and the possibility of $\mathrm{Pb}$ make evaluation of the single analyses difficult. In some cases, additional analyses of the same age (i.e. additional spot analyses) were retrieved allowing the data to be pooled for a betterconstrained age for the detrital grain. Data from the detrital samples, in particular the younger data, are examined in terms of statistical age populations, which are interpreted to be more robust than a single analysis. Data that are $<5 \%$ discordant are represented in cumulative probability plots (Sircombe 2000). For detrital grains $>1000 \mathrm{Ma}$, the ${ }^{207} \mathrm{~Pb} /{ }^{206} \mathrm{~Pb}$ age is used in the cumulative probability plot and for data $<1000 \mathrm{Ma}$, the ${ }^{206} \mathrm{~Pb} /{ }^{238} \mathrm{U}$ age is used (Compston et al. 1992; Nemchin and Cawood 2005) (Figs. 7, 8, 9).

\section{ANALYTICAL RESULTS}

\section{Martinon Formation (Brookville belt)}

Sample VL-2001-05 from quartzite-pebble conglomerate of the Martinon Formation contains detrital zircons ranging in size from about 60 to $250 \mu \mathrm{m}$ in the longest dimension. Well faceted, euhedral crystals ranging in morphology from equant and multifaceted to elongate are abundant. Subround to round, frosted and pitted grains ranging in colour from colourless to light brown are also present in the sample. The zircons range in quality from beautiful clear crystals to those with abundant fractures, inclusions, and apparent cores (Fig. 5a, 6a).

A statistical age population, defined by $24 \%$ of the analyses, has a Neoproterozoic age of $635 \pm 4 \mathrm{Ma}(\mathrm{MSWD}=1.05$, probability $=0.40, \mathrm{n}=13)$. Other statistically significant Neoproterozoic populations are at $674 \pm 8 \mathrm{Ma}(\mathrm{MSWD}=1.5$, probability $=0.13, \mathrm{n}=10)$ and $602 \pm 8 \mathrm{Ma}(\mathrm{MSWD}=1.4$, probability $=0.21, \mathrm{n}=8$ ), and the latter is considered to represent the maximum depositional age of the conglomerate (Fig. 7a). Analyses from grain 43 (two spots - 43.1, 43.2 in Table A1) and grain 34 (two spots - 34.1, 34.2, in Table A1) are not considered in the cumulative probability plot as both of these grains show evidence for Pb loss. Detritus of Mesoproterozoic age comprise $27 \%$ of the analyses and range in age from $~ 1.58$ to $\sim 1.07 \mathrm{Ga}$. A few Paleoproterozoic ( 2.18 to $\sim 1.91 \mathrm{Ga})$ grains and a single Archean $(\sim 2.57 \mathrm{Ga})$ grain were also analysed (Fig. 8a; Table A1).

\section{Flagg Cove Formation (Grand Manan Island belt)}

Sample VL-2001-10 from quartzose sandstone of the Flagg Cove Formation contains detrital zircon grains with a range of morphologies including well faceted crystals ranging from equant to elongate in shape, and abundant subround to round grains. Overall, the size of zircon grains in the sample is fairly consistent and quite small (mostly $<50$ to $<100 \mu \mathrm{m}$ in the 

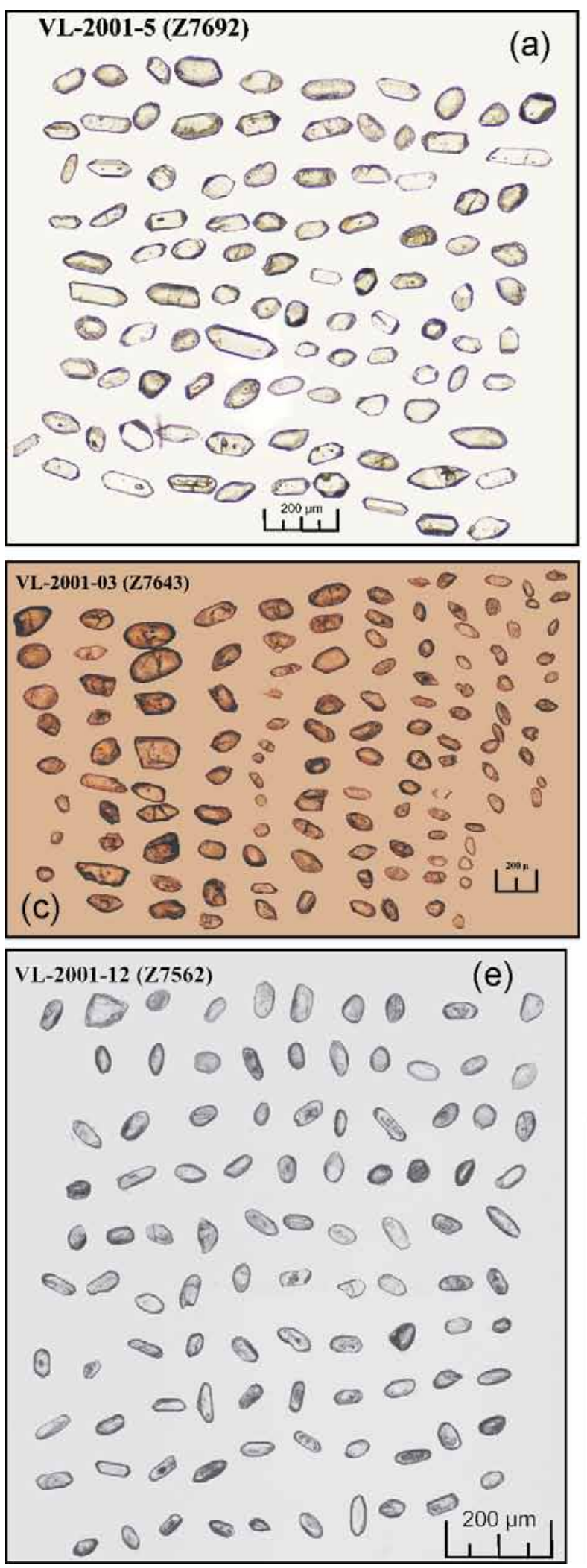

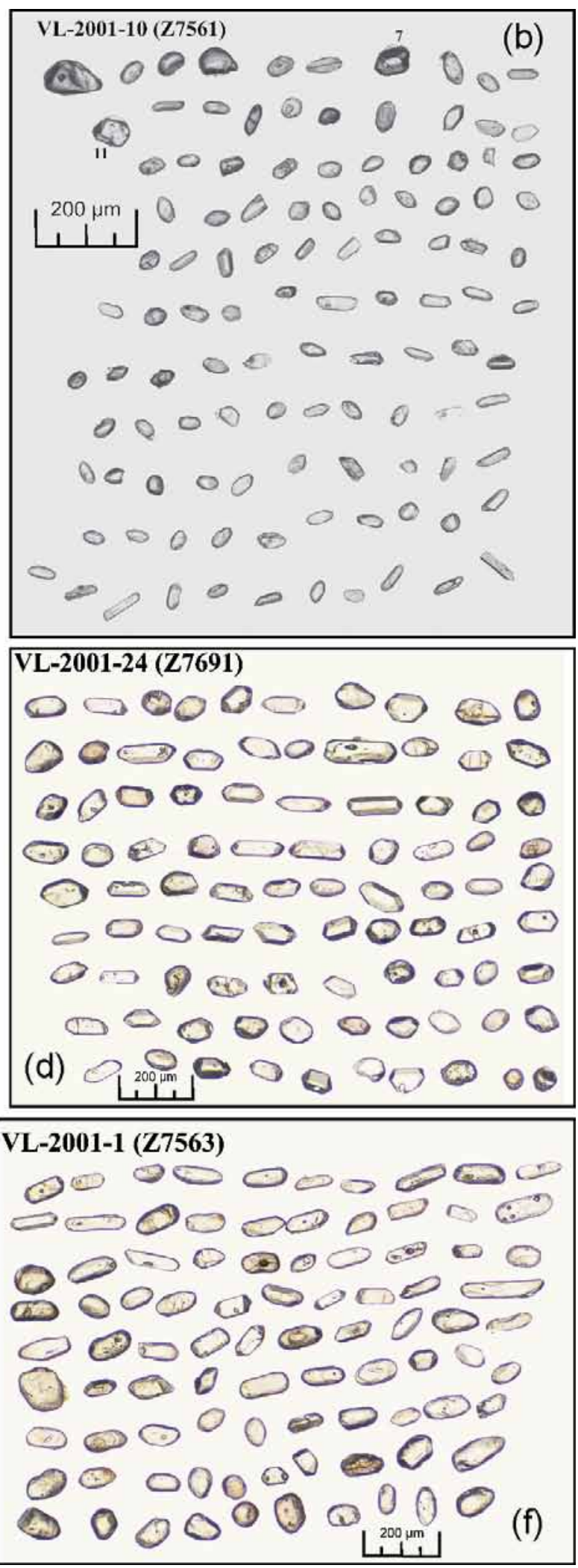

Fig. 5. Transmitted light photograph of the detrital zircons: (a) Martinon Formation(Sample VL-2001-05 on SHRIMP Mount \#IP295; (b) Flagg Cove Formation (Sample VL-2001-10 on SHRIMP Mount \#IP296); (c) Matthews Lake Formation (Sample VL-2001-03 on SHRIMP Mount \#IP286); (d) Ellsworth Formation (Sample VL-2001-24 on SHRIMP Mount \#IP295); (e) Calais Formation (Sample VL-2001-12 on SHRIMP Mount \#IP296); (f) Baskahegan Lake Formation (Sample VL-2001-01 on SHRIMP Mount \#IP295). 

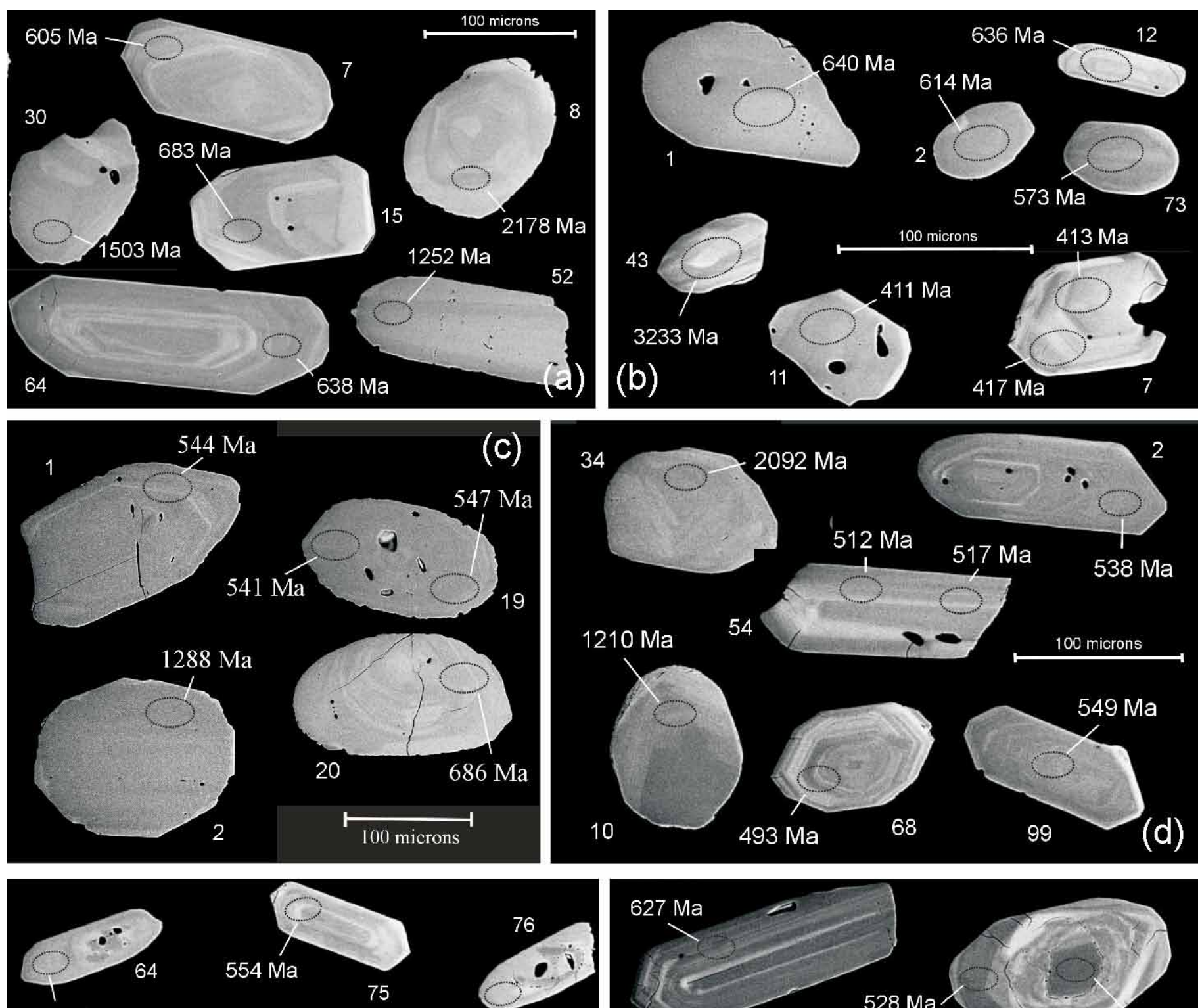

$528 \mathrm{Ma}$

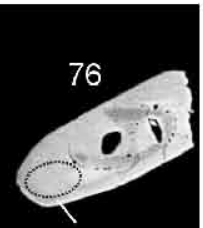

$510 \mathrm{Ma}$
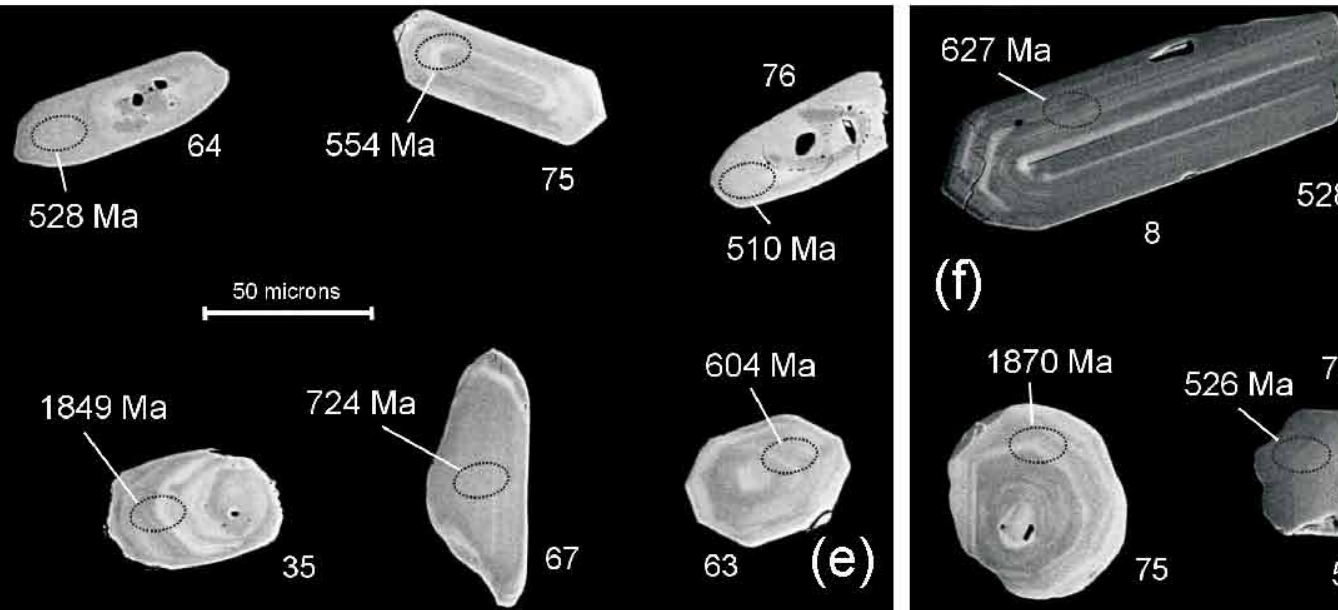

(f)

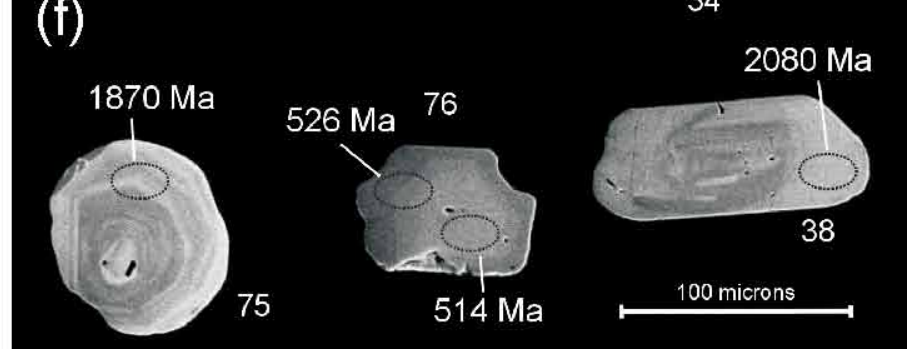

Fig. 6. Representative BSE SEM images of detrital zircons with location of the SHRIMP spots: (a) Martinon Formation (Sample VL-2001-05); (b) Flagg Cove Formation (Sample VL-2001-10); (c) Matthews Lake Formation (Sample VL-200103); (d) Ellsworth Formation (Sample VL-2001-24); (e) Calais Formation (Sample VL-2001-12); (f) Baskahegan Lake Formation (Sample VL-2001-01). 
ATLANTIC GEOLOGY · VOLUME $45 \cdot 2009$
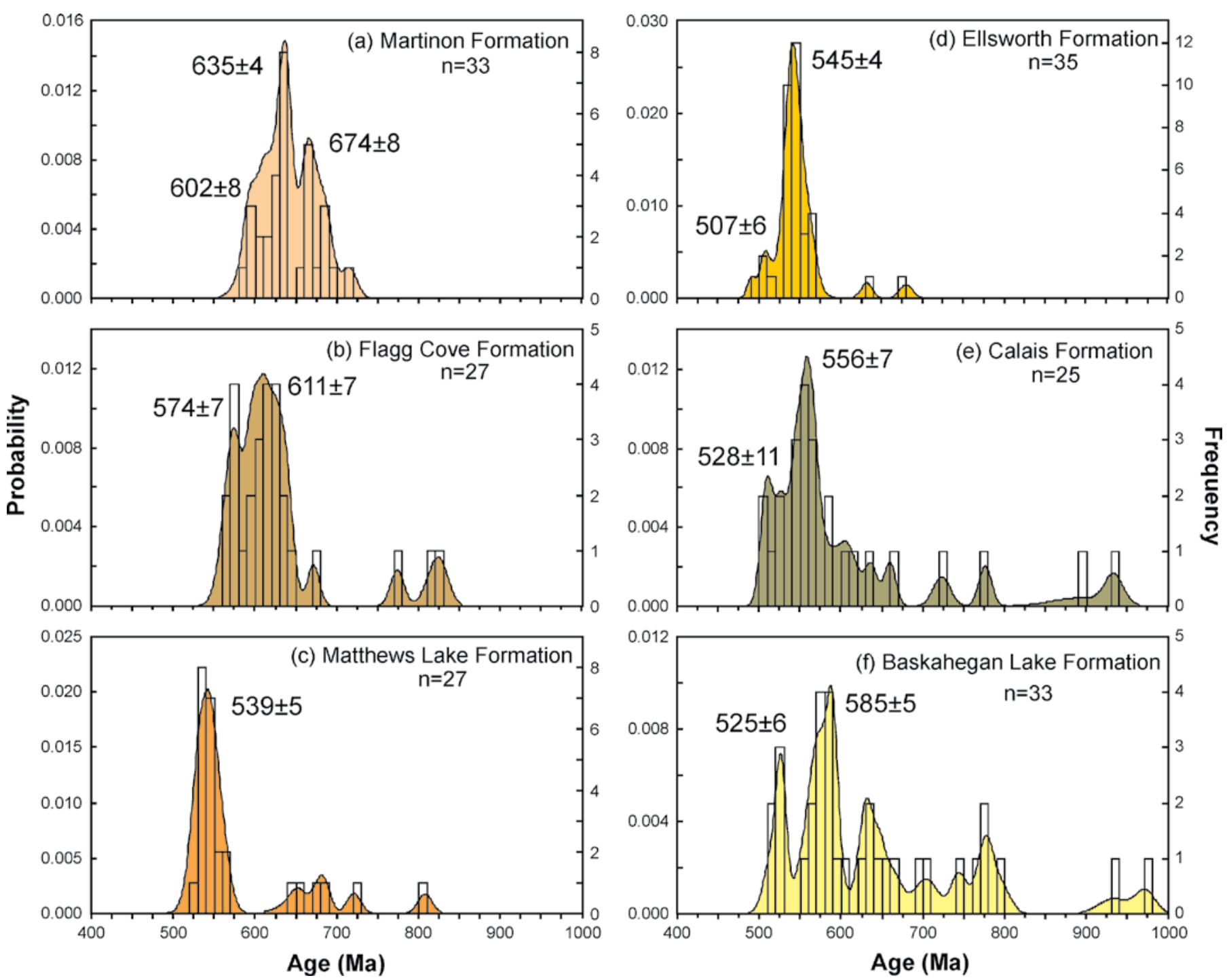

Fig. 7. Cumulative probability plots of the data ranging in age between 400-1000 Ma: (a) Martinon Formation (Sample VL-2001-05); (b) Flagg Cove Formation (Sample VL-2001-10); (c) Matthews Lake Formation (Sample VL-2001-03); (d) Ellsworth Formation (Sample VL-2001-24); (e) Calais Formation (Sample VL-2001-12); (f) Baskahegan Lake Formation (Sample VL-2001-01).

longest dimension, with many $\leq 50$ microns in size). Many grains have cores, abundant inclusions, and/or fractures, but also present are high quality, optically clear grains (Fig. 5 b).

The dominant statistical age population in the sample ( $30 \%$ of the analyses) has a Neoproterozoic age of $611 \pm 7$ $\mathrm{Ma}(\mathrm{MSWD}=2.2, \mathrm{n}=13$ grains). Also present is a younger Neoproterozoic age population of $574 \pm 7 \mathrm{Ma}(\mathrm{MSWD}=0.69$, probability $=0.66, \mathrm{n}=7$ grains), which is considered to represent the maximum depositional age of the sandstone (Fig. 7b). Other zircons of Neoproterozoic age range from $\sim 828$ to $\sim 672$ Ma. Rare detrital zircons of Mesoproterozoic ( 1.44 to $\sim 1.34$ $\mathrm{Ga})$, Paleoproterozoic $(\sim 2.44$ to $\sim 1.74 \mathrm{Ga})$, and $\operatorname{Archean}(\sim 3.23$ to $\sim 2.90 \mathrm{Ga}$ ) age are also represented in the sandstone (Fig. $8 b$; Table A2).

Two analyses at $507 \mathrm{Ma}$ from a single zircon (grain 91) are not included in the cumulative probability plot as they are slightly discordant, have low $\mathrm{U}$ contents, and are from a grain which contains some fractures. These data are not of sufficient quality to evaluate if grains of this age are present in this sample. However, two other zircon grains (grains 7 and 11, Table A2; not plotted) also yielded Paleozoic ages and these two grains contain sufficient $U$ to produce good quality analyses. These two grains are similar in morphology (stubby to equant) and are slightly larger than most of the detrital zircons in the sample (Figs. 5b, 6b). The data include two overlapping reproducible analyses from grain 7, and one analysis from grain 11 (Table A2), all of which are concordant. A weighted average of these analyses has an age of $414 \pm 6 \mathrm{Ma}(\mathrm{MSWD}=0.36$, probability $=0.70, n=3$ ). Although the data are of good quality, the two grains are interpreted to be contaminants, possibly from 

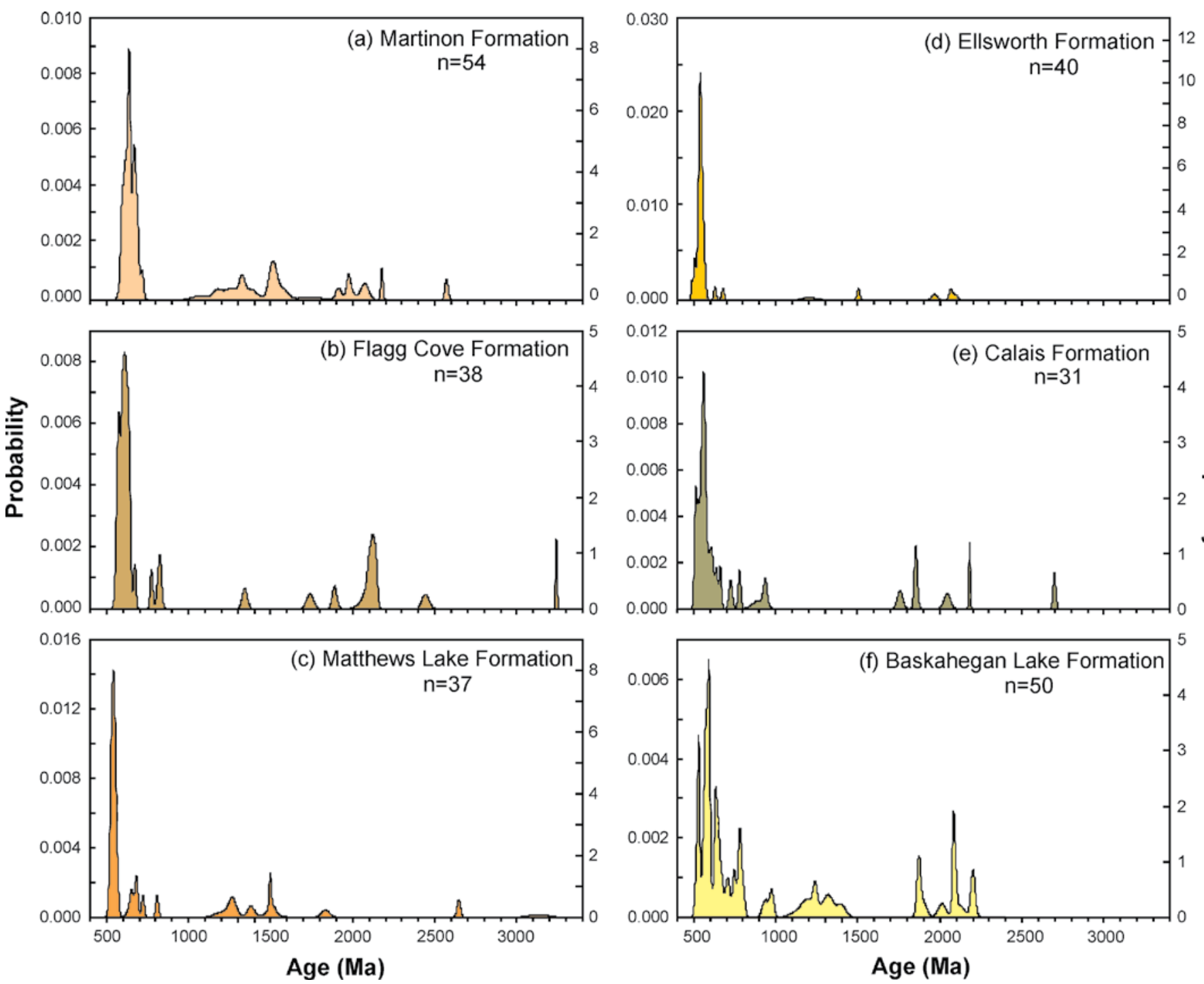

Fig. 8. Cumulative probability plots of all the data: (a) Martinon Formation (Sample VL-2001-05); (b) Flagg Cove Formation (Sample VL-2001-10); (c) Matthews Lake Formation (Sample VL-2001-03); (d) Ellsworth Formation (Sample VL-200124); (e) Calais Formation (Sample VL-2001-12); (f) Baskahegan Lake Formation (Sample VL-2001-01).
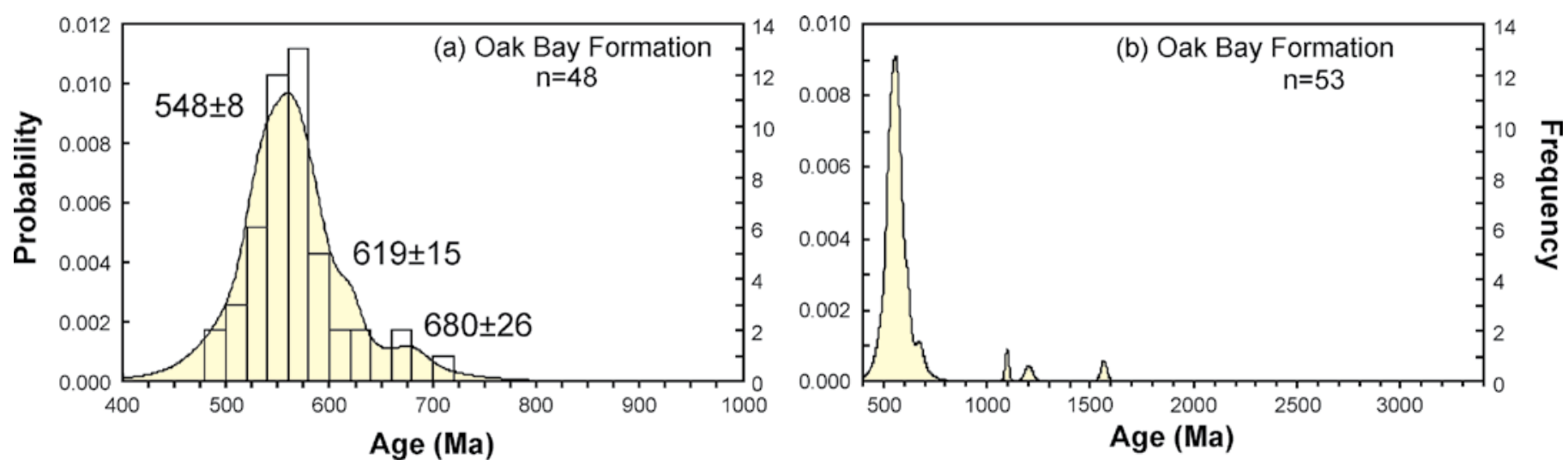

Fig. 9. Cumulative probability plots of the data from the Oak Bay Formation (Sample 21G/3g-1A): (a) data ranging in age between 400-1000 Ma; (b) all the data. 
thin glassy quartz veins that are not easy to differentiate from the quartz-rich sedimentary host, as field relationships indicate that the Flagg Cove Formation was intruded by the $\sim 535 \mathrm{Ma}$ Stanley Brook Granite (Miller et al. 2007).

\section{Matthews Lake Formation (New River belt)}

Sample VL-2001-03 from quartzose sandstone of the Matthews Lake Formation contains detrital zircon grains with a wide range of morphologies from well rounded, frosted and pitted grains to sharply faceted euhedral crystals. Zircon grains selected for SHRIMP analysis vary in size ( 75 to $300 \mu \mathrm{m})$ and quality and include optically clear grains, those that contain colourless fluid or dark opaque inclusions, grains with abundant fractures, and grains with cores (Figs. 5c, 6c).

A single statistical age population of $539 \pm 5 \mathrm{Ma}$ (MSWD $=1.2$, probability $=0.25, \mathrm{n}=17$ ), which spans the Neoproterozoic-Paleozoic boundary, dominates the sample ( $40 \%$ of the analyses), and provides a maximum depositional age for the sandstone (Fig. 7c). Other significant contributions include detritus of Mesoproterozoic ( 1.50 to $\sim 1.20 \mathrm{Ga})$ and Neoproterozoic ( $~ 808$ to $\sim 644 \mathrm{Ma}$ ) age. Rare grains of Paleoproterozoic $(1.83 \mathrm{Ga})$ and Archean $(\sim 3.14$ to $\sim 2.65 \mathrm{Ga})$ age were analysed from this sample (Fig. 8c; Table A3).

\section{Ellsworth Formation (Ellsworth belt)}

Sample VL-2001-24 from quartzose sandstone of the Ellsworth Formation contains detrital zircon grains dominated by well-faceted grains ranging in morphology from multi-faceted crystals to stubby prismatic grains to elongate crystals. Subround to round, colourless to light brown grains are less common, but were also analyzed. Zircons with a range of quality were analyzed, from grains with abundant inclusions and fractures to high quality, clear, colourless, well faceted crystals. Zircons with cores are also present in the sample. The zircon grains range in length from about 50 to $200 \mu \mathrm{m}$ (Fig. 5d).

A dominant statistical age population $(73 \%$ of the analyses) with an age of $545 \pm 4 \mathrm{Ma}$ (MSWD $=1.6, \mathrm{n}=28$, spans the Neoproterozoic-Paleozoic boundary. Younger Paleozoic grains are also present in the sample and define a statistical age population of $507 \pm 6 \mathrm{Ma}(\mathrm{MSWD}=1.2$, probability $=0.33, \mathrm{n}=6$ analyses on four grains). Two of these younger zircons have reproducible analyses: grain 54 has two overlapping analyses with a weighted average of $515 \pm 11 \mathrm{Ma}(\mathrm{MSWD}=0.21$, probability $=0.65$; Fig. $6 \mathrm{~d}$ ), and grain 67 has two overlapping analyses with a weighted average of $506 \pm 11 \mathrm{Ma}(\mathrm{MSWD}=0.59$, probability $=0.44$; Table A4). These grains likely indicate a maximum depositional age for the Ellsworth Formation of $\sim 507 \mathrm{Ma}$. Rare detrital zircons of Neoproterozoic ( 680 and $\sim 632 \mathrm{Ma})$, Mesoproterozoic $(\sim 1.50$ and $\sim 1.21 \mathrm{Ga})$ and Paleoproterozoic ( 2.09 to $\sim 1.97 \mathrm{Ga})$ age were also analysed from the sample (Fig. 8d; Table A4).

\section{Calais Formation (St. Croix belt)}

Sample VL-2001-12 from sandstone of the Calais Formation contains detrital zircon grains that are consistently small, ranging from about 50 to $<100 \mu \mathrm{m}$ in the longest dimension. The grains exhibit a range of morphologies including subround to round grains, and equant to prismatic euhedral crystals. High quality, clear zircons are common in the sample but grains with abundant fractures, inclusions, and cores are also present (Fig. 5e).

The most dominant statistical age population in the sample ( $30 \%$ of the analyses) has a Neoproterozoic age of $556 \pm 7$ $\mathrm{Ma}(\mathrm{MSWD}=1.6$, probability $=0.10, \mathrm{n}=10$; Fig. $7 \mathrm{e})$. Younger Paleozoic zircons include three detrital grains defining a statistical population of $510 \pm 8 \mathrm{Ma}(\mathrm{MSWD}=0.51$, probability $=0.60, \mathrm{n}=3)$ and two grains at $528 \pm 11 \mathrm{Ma}(\mathrm{MSWD}=0.017$, probability $=0.90$; Fig. $6 \mathrm{e})$. The analyses from these younger concordant grains contain a sufficient amount of $U$ to produce good quality data, and are likely to provide a maximum depositional age for the Calais Formation. Neoproterozoic ( 936 to $\sim 580 \mathrm{Ma}$ ), Paleoproterozoic $(2.18$ to $\sim 1.76 \mathrm{Ga}$ ), and minor Archean $(2.70$ and $\sim 2.60 \mathrm{Ga})$ grains are also present in the sample (Fig. 8e; Table A5).

\section{Baskahegan Lake Formation (Miramichi belt)}

Sample VL-2001-01 from quartzose sandstone of the Baskahegan Lake Formation contains detrital zircon grains with a wide range of morphologies from well-rounded, light pink grains to sharply faceted, colourless, euhedral crystals including some delicate elongate grains (Fig. 5f). Grains selected for SHRIMP analysis ranged in length from about 75 to $300 \mu \mathrm{m}$. A range of zircon quality was also represented on the mount and includes grains that are optically clear, those that contain colourless fluid or dark opaque inclusions and abundant fractures, and grains with cores (Fig. 6f).

The youngest statistical age population has an Early Cambrian age of $525 \pm 6 \mathrm{Ma}(\mathrm{MSWD}=0.56$, probability $=0.69$, $\mathrm{n}=5$ analyses on four grains; Fig. 7f). Two reproducible spots on one grain (grain 76; Fig. 6f) have an age of $522 \pm 11 \mathrm{Ma}$ $(\mathrm{MSWD}=1.02$, probability $=0.31)$. A statistical population with a Neoproterozoic age of $585 \pm 5 \mathrm{Ma}(\mathrm{MSWD}=0.90$, probability $=0.53, \mathrm{n}=10$ ) comprises about $20 \%$ of the analyses. Older Neoproterozoic zircons, ranging in age between 796 and $627 \mathrm{Ma}$, comprise about $25 \%$ of the analyses. The sandstone also contains detrital grains of Mesoproterozoic $(\sim 1.40$ to $\sim 1.15 \mathrm{Ga})$, and Paleoproterozoic $(\sim 2.20$ to $\sim 1.87 \mathrm{Ga})$ age (Fig. 8f; Table A6).

\section{Oak Bay Formation (Silurian cover)}

Results from 53 detrital zircons from crushed igneous pebbles and matrix of a conglomerate sample $(21 \mathrm{G} / 3 \mathrm{~g}-1 \mathrm{~A})$ from the Oak Bay Formation are divided into the following 
populations, although large analytical errors in this particular sample produces considerable overlap at the younger end of the age spectrum (Fig. 9): a dominant Neoproterozoic statistical age population of $548 \pm 8 \mathrm{Ma}(\mathrm{MSWD}=1.5$, probability $0.05, \mathrm{n}=35$ ); additional Neoproterozoic populations at $619 \pm 15 \mathrm{Ma}(\mathrm{MSWD}=0.38$, probability $0.77, \mathrm{n}=4)$ and $680 \pm 26 \mathrm{Ma}(\mathrm{MSWD}=0.19$, probability $0.83, \mathrm{n}=3$ ); and rare Mesoproterozoic grains in the range 1.57 to $1.10 \mathrm{Ga}$ (Table A7). The age of a single granite cobble $(21 \mathrm{G} / 3 \mathrm{~g}-1 \mathrm{~B})$ was determined to be $549 \pm 16 \mathrm{Ma}$.

\section{IMPLICATIONS FOR DEPOSITIONAL AGES}

The minimum detrital zircon age populations in the samples (Table 1) provide maximum absolute ages for the six dated Ganderian units, which were only partly constrained previously by stratigraphic relations and dated cross-cutting plutons (Fig. 3). The time scale followed here is from Gradstein et al. (2004).

\section{Martinon Formation}

Detrital zircon dates indicate that the maximum age of deposition for the Martinon Formation is $602 \pm 8 \mathrm{Ma}$ (Ediacaran), based on the youngest statistical age population in quartzite pebble conglomerate at Ludgate Lake. The minimum age of the conglomerate is $546 \pm 2 \mathrm{Ma}$, the age of the cross-cutting Ludgate Lake Granodiorite of the Golden Grove Plutonic Suite (White et al. 2002). Previously, the Martinon Formation was assumed to be much older than Ediacaran, based on its stratigraphic position overlying the Ashburn Formation. The latter has a maximum depositional age of $\sim 1.23 \mathrm{Ga}$ (Table 1 ) based its detrital zircon content, and a minimum age of $\sim 550 \mathrm{Ma}$ constrained by cross-cutting plutons (Barr et al. 2003c). However, the nature of the stratigraphic contact between the two formations is uncertain with Alcock (1938), Leavitt (1963), Nance (1987), and Currie (1991) considering it to be an unconformity, and Wardle (1978) and White (1996) interpreting it as a gradational boundary. The presence of an unconformity between the Martinon and Ashburn formations was based on the interpretation of a carbonate conglomerate as a basal conglomerate in the Martinon Formation, whereas White (1996) and White and Barr (1996) interpreted the conglomerate to be an olistostrome, in which the carbonate clasts were not fully lithified prior to their incorporation in the Martinon sandstone matrix. Such olistostrome lenses occur at several locations in the Martinon Formation, not just at the base, and sandstone similar to the Martinon Formation occurs interbedded with marble of the Ashburn Formation on Green Head Island (White 1996). Therefore, White (1996) and White and Barr (1996) considered a major unconformity between the two formations to be unlikely. Irrespective of the interpreted Ashburn-Martinon relationship, the lack of a Neoproterozoic zircon population in quartzite from the Ashburn Formation and its presence in con- glomerate of the Martinon Formation are consistent with Late Neoproterozoic uplift and exhumation of the Brookville belt.

\section{Flagg Cove Formation}

The maximum age of deposition of the Flagg Cove Formation is $574 \pm 7$ Ma based on the youngest statistical age population of detrital zircons in quartzose sandstone sample VL-2001-1 (Table 1). Its minimum age of deposition is $535 \pm 3$ $\mathrm{Ma}$, the age of the cross-cutting Stanley Brook Granite (Miller et al. 2007). The age of the Flagg Cove Formation is, therefore, restricted to between mid-Ediacaran and earliest Cambrian.

The detrital zircon data circumstantially provides some age constraints on the undated Long Island Bay Formation as this formation was likely a source of detritus for the overlying Flagg Cove Formation. Volcanic clasts derived from the Long Island Bay Formation are present in unconformably overlying conglomerate of the Great Duck Island Formation on Long Island. These clasts in turn may have been reworked and incorporated into the overlying sandstone sequence of the Flagg Cove Formation. Abundant small stubby prismatic zircons, typical of volcanic rocks, were retrieved from the Flagg Cove sample and are consistent with the above observation (Fig. 5b). The volcanic rocks of the Long Island Bay Formation, therefore, are likely to be no younger than $574 \pm 7 \mathrm{Ma}$, the youngest statistical detrital zircon age population in the Flagg Cove sample.

\section{Matthews Lake Formation}

The youngest and dominant detrital zircon population in the sample from the type area of the Matthews Lake Formation has an age of $539 \pm 5 \mathrm{Ma}$, which provides constraints on its maximum age of deposition. The age range of this population spans the Ediacaran-Cambrian boundary and is consistent with a local basement source that includes the Ragged Falls Granite dated at $553 \pm 2 \mathrm{Ma}$ and volcanic rocks of the Simpsons Island Formation dated at $539 \pm 4 \mathrm{Ma}$ (Johnson and McLeod 1996; Johnson 2001; Barr et al. 2003a; McLeod et al. 2003). The absence of younger zircon ages in the sample, the "clean" nature of the sandstone, and observations to the northeast that the quartzose sandstone sequence appears to lie directly on Neoproterozoic basement suggest that the Matthews Lake Formation underlies, rather than overlies, volcanic rocks of the Mosquito Lake Road Formation dated at $514 \pm 2 \mathrm{Ma}$ (McLeod et al. 2003). If the Matthews Lake sandstone were correlative with the polymictic conglomerate that overlies the Mosquito Lake Road volcanic rocks, it would be likely to contain volcanic detritus and zircon as young as late Early Cambrian.

\section{Ellsworth Formation}

The youngest statistical detrital zircon age population in the sandstone sample from the Ellsworth Formation has an age of $507 \pm 6 \mathrm{Ma}$. The source of these Middle Cambrian zircon grains 
is most likely felsic tuff of the Ellsworth Formation (dated at $509 \pm 1 \mathrm{Ma}$ ). Abundant sharply faceted prismatic zircons retrieved from the sample are consistent with this interpretation (Fig. 5d). Although complex deformation makes it difficult to determine the exact stratigraphic position of the sandstone beds within the Ellsworth Formation, they are unlikely to be younger than the volcanic rocks of the Castine Formation (dated at $504 \pm 3 \mathrm{Ma}$ ), which unconformably overlie the Ellsworth Formation in the Penobscot Bay area (Ruitenberg et al. 1993; Schultz et al. 2008). The dominant population of $545 \pm 4$ Ma in the Ellsworth sandstone suggests that basement rocks underlying the Middle Cambrian Ellsworth Formation were likely correlative with those of the New River belt but such Neoproterozoic rocks have yet to be identified in Maine.

\section{Calais Formation}

The youngest statistical detrital zircon population in the sandstone sample from the Calais Formation indicates that its maximum age of deposition is $510 \pm 8 \mathrm{Ma}$, i.e. Middle Cambrian. The minimum age of the sample is early Tremadocian ( 479 $\mathrm{Ma}$ ) based on graptolites found on Cookson Island near the collection site (Fyffe and Riva 1990). The zircon grains were likely derived from reworking of detritus from intraformational tuff beds $(503 \pm 5 \mathrm{Ma}$; Tucker et al. 2001) found lower in the section in Maine; other possible sources include volcanic rocks of the Ellsworth Formation (509 $\pm 1 \mathrm{Ma}$ ) and Castine Formation (504 $\pm 3 \mathrm{Ma}$ ) (Ruitenberg et al. 1993; Schultz et al. 2008).

\section{Baskahegan Lake Formation}

The youngest statistical detrital zircon population in the sandstone sample from the Baskahegan Lake Formation indicates that the maximum age of deposition is $525 \pm 6 \mathrm{Ma}$, i.e. Early Cambrian. The minimum age of deposition is early Tremadocian ( 488 Ma) based on the presence of graptolites in the conformably overlying Bright Eye Brook Formation. The sampled part of this formation is either older than the Calais Formation, or did not have access to detritus from the same $\sim 509$ to 504 Ma volcanic units.

\section{IMPLICATIONS FOR SEDIMENT PROVENANCE}

In addition to the minimum detrital age populations discussed above, all of the samples contain a range of older zircon grains, a few as old as Archean (Table 1). Previously published zircon data from the Ganderian belts including detrital zircon ages from the Ashburn Formation of the Green Head Group (Barr et. al. 2003c); xenocrystic zircon ages from diabasic dykes that intrude the Woodstock Group (David et al. 1991); xenocrystic zircon data from the Meridian Brook Granite, which intrudes the Miramichi Group in north-central New Brunswick (Roddick and Bevier 1995); and xenocrystic zircon data from the Middle River Rhyolite, which is interbedded with sedimen- tary rocks of the Patrick Brook Formation near the top of the Miramichi Group in northeastern New Brunswick (McNicollet al.2002), all contain essentially the same range of age populations as determined in this study.

\section{Neoproterozoic to Ordovician populations}

Althoughall of the samplesaredominated byNeoproterozoic zircon populations, these populations differ in detail (Fig. 7). The Martinon Formation is dominated by populations with ages of $635 \pm 4 \mathrm{Ma}, 674 \pm 8 \mathrm{Ma}$, and $602 \pm 8 \mathrm{Ma}$, whereas the likely somewhat younger Flagg Cove Formation is dominated by populations at $611 \pm 7 \mathrm{Ma}$ and $574 \pm 7 \mathrm{Ma}$, and also contain a few grains with ages of 828 to 752 Ma not seen in the Martinon sample. Basement rocks such as the gneiss dated at $\sim 675 \mathrm{Ma}$ in the Ganderian Hermitage Flexure of Newfoundland (ValverdeVaquero et al. 2006) are possible sources of the $674 \pm 8 \mathrm{Ma}$ zircons in the Martinon Formation. Possible sources for the $635 \pm 4$ and $602 \pm 8 \mathrm{Ma}$ zircon grains are the $\sim 629$ to $\sim 611 \mathrm{Ma}$ volcanic and plutonic rocks in the Grand Manan Island and New River belts. Arc-related comagmatic volcanic and plutonic complexes dated at $\sim 685$ to $\sim 670 \mathrm{Ma}$ and $\sim 635$ to $\sim 575 \mathrm{Ma}$ in Avalonia of Nova Scotia and Newfoundland (Bevier et al. 1993; O’Brien et al. 1996; Keppie et al. 1998) are also possible regional sources if Avalonia was close to Ganderia in the Late Neoproterozoic-Early Paleozoic. Volcanic rocks of the Ingalls Head Formation dated at $618 \pm 3 \mathrm{Ma}$ and intrusive rocks of the Three Islands Granite dated at $611 \pm 2 \mathrm{Ma}$ (Miller et al. 2007) are likely local sources for the $611 \pm 7 \mathrm{Ma}$ detrital zircons in the Flagg Cove Formation.

Zircon age populations that are close to the EdiacaranCambrian boundary dominate in the Matthews Lake Formation (539 $\pm 5 \mathrm{Ma})$, Ellsworth Formation $(545 \pm 4 \mathrm{Ma})$, Calais Formation ( $556 \pm 7 \mathrm{Ma}$ and $528 \pm 11 \mathrm{Ma}$ ), and Oak Bay Formation ( $548 \pm 8 \mathrm{Ma}$ and $549 \pm 16 \mathrm{Ma})$. These dominant populations were likely derived from detritus present in igneous units from the Brookville, Grand Manan Island and New River belts of southern New Brunswick (Johnson and McLeod 1996; Currie and McNicoll 1999; Johnson 2001; White et al. 2002; Bartsch and Barr 2005). The presence of abundant large Neoproterozoic igneous clasts in the Oak Bay Formation indicates that the basement rocks of southern New Brunswick underwent significant uplift in the Early Silurian.

The Matthews Lake, Calais, and Oak Bay formations have a scattering of older Neoproterozoic ages in the 934 to 630 Ma range, whereas only two zircon grains in that range were analysed in the Ellsworth sandstone. The Baskahegan Lake Formation is dominated by zircon grains with an Ediacaran age of $585 \pm 5 \mathrm{Ma}$, but also contains a relatively large population in the range 973 to $627 \mathrm{Ma}$, similar to the Matthew Lakes, Calais and Oak Bay formations. However, no igneous units older than $629 \pm 1$ Ma have yet to be identified in these belts, so the sources of the older grains are uncertain. Plutonic rocks such as those dated at $584 \mathrm{Ma}$ in the Ganderian Hermitage Flexure of Newfoundland (Valverde-Vaquero et al. 2006) could be a source for dominant age population in the Baskahegan 
Lake Formation. Igneous units with ages of $\sim 685-670 \mathrm{Ma}$, and $760 \mathrm{Ma}$ are known in Avalonia (Bevier et al. 1993; O’Brien et al. 1996; Keppie et al. 1998) and are potential sources if Avalonia were nearby.

\section{Mesoproterozoic and older populations}

Except for the sample from the Calais Formation, all other samples contain small populations of Mesoproterozoic detrital zircon grains in the range from 1.61 to $1.07 \mathrm{Ga}$ and lack Paleoproterozoic detrital zircons in the range 2.5 to $2.3 \mathrm{Ga}$ (Fig. 8). Such age populations suggest that the various faultbounded belts had their origins along the northern or western margin of the Amazonian craton rather than West Africa (van Staal et al. 1996; Keppie et al.1998). Previously published data on detrital zircons from the Ashburn Formation of the Brookville belt; and on the ages of granodiorite cobbles from the basal part of the Tetagouche Group and on xenocrystic zircons from intrusive rocks of the Miramichi belt, are also consistent with an Amazonian provenance (Roddick and Bevier 1995; van Staal et al. 1996; Barr et al. 2003c).

\section{DISCUSSION}

Global plate tectonic reconstructions based on paleomagnetic, isotopic, and detrital zircon studies (including the new zircon data presented above) place Ganderia and Avalonia along the periphery of the Amazonian craton in the Neoproterozoic. These reconstructions either treat Ganderia and Avalonia as a single microcontinent (Murphy and Nance 1989; Nance and Murphy 1994; Keppie et al. 1996, 1998; Murphy et al. 2000; Nance et al. 2002), or as two distinct microcontinents that were brought into juxtaposition by strike-slip faults with Avalonia originally positioned further east, possibly bridging the gap that separated Amazonia from West Africa (van Staal et al. 1996; 1998; Rogers et al. 2006). The latter interpretation is adopted herein. Although Ganderia and Avalonia may have shared a common cover sequence by the Early Cambrian (Johnson 2001; Landing et al. 2008), it should be pointed out that this supposed 'cover sequence' occurs in separate faulted basins and cannot be proven to have been continuous between Ganderia and Avalonia. Furthermore, the assumption that Ganderia and Avalonia formed a single microcontinent with the more juvenile part of an arc lying outboard of the Amazonian craton requires the microcontinent to make a $180^{\circ}$ rotation prior to its accretion to Laurentia (Keppie et al. 1996). Such a rotation is unnecessary if these microcontinents rifted from the Gondwanan margin as separate entities.

Reconstruction of the paleogeographic relationships between fault-bounded belts is a difficult problem because evidence of linkages between ancient oceanic tracts and continental margins have largely been destroyed, particularly so if the region have been involved in multiple orogenic cycles. The global plate tectonic model of Nance et al. (2002) that places a southward-dipping subduction zone along the northern mar- gin for Gondwana during the Neoproterozoic is accepted here as the basic framework in which to discuss possible inter-relationships among the various belts that make up Ganderia in New Brunswick and coastal Maine. Similarities and differences in the stratigraphy, magmatic history, isotopic signatures, and detrital zircon populations of these belts are examined below in order to determine the possible paleotectonic evolution of the region during the period from the late Neoproterozoic to Early Paleozoic.

The presence of xenocrystic zircons and overlapping mainly negative $\varepsilon_{\mathrm{Nd}}$ signatures in Neoproterozoic igneous rocks of the Brookville, Grand Manan Island, and New River belts suggests that the volcanic and plutonic rocks in these belts were derived from a similar source containing a component of highly evolved continental crust (Hodgins 1994; Samson et al. 2000). It is noteworthy that the $>600$ Ma magmatic activity that affected the platformal carbonate rocks of the Kent Island Formation of the Grand Manan Group is absent from similar carbonates of the Ashburn Formation of the Green Head Group. This relationship suggests that during this period, the Brookville belt represented a more stable inboard position within the Ganderian segment of the Amazonian upper-plate hinterland relative to the active outboard margin represented by the Grand Manan Island and New River belts. This same relationship is also evident in the Ganderian belts of Cape Breton Island where $>600$ Ma plutons occur in the western Aspy (= New River) belt in northwestern Cape Breton Island but are absent in the Bras d'Or (= Brookville) belt to the southeast (Barr and Raeside 1989; Lin et al. 2007).

The Grand Manan Island and New River belts have a similar episodic magmatic history, respectively spanning the time intervals from $\sim 618$ to $\sim 535 \mathrm{Ma}$ and $\sim 629$ to $\sim 539 \mathrm{Ma}$ (Currie and Hunt 1991; Currie and McNicoll 1999; Barr et al. 2003a,b; Black et al. 2004; McLeod et al. 2003; Miller et al. 2007), consistent with their being proximal components of a single, structurally telescoped Ganderian continental margin rather than representing far-travelled exotic terranes. Although data are somewhat limited, the difference in the age of $>600$ Ma plutonism in the New River belt ( 622 to $\sim 629 \mathrm{Ma})$ compared to that on Grand Manan Island ( $611 \mathrm{Ma})$ suggests that the magmatic activity in the latter belt may have been related to extension in a back-arc basin and/or the onset of rifting of Ganderia from the Amazonian craton. Under this scenario, volcanic rocks > $630 \mathrm{Ma}$ in the New River belt are expected to have an arc signature but as yet no supracrustal rocks have yet been identified that are intruded by the older plutonic suite.

A significant time gap exists between the older $\sim 629$ to $\sim 611 \mathrm{Ma}$ and younger $\sim 553$ to $\sim 535 \mathrm{Ma}$ magmatic events documented in both the Grand Manan Island and New River belts (Fig. 3). It was during this gap in volcanic activity that the carbonate breccia, clastic siltstone, and quartz-pebble conglomerate of the Martinon Formation were deposited, possibly unconformably on the platformal stromatolitic carbonates and quartzose sandstone of the Ashburn Formation. If correct, this unconformable relationship appears to be a unique feature restricted to the Ganderian basement rocks of southern New 
Brunswick and may be related to a tectonic event localized along this segment of the Proterozoic Amazonian continental margin. The extensional or compressional nature of subduction along a plate boundary is controlled by a number of factors including relative convergent rate, age of the subducting slab, absolute motion of the overriding plate, and ridge-trench collision (Dewey 1980).

Localized collision of an aseismic ridge with the Ganderian segment of the Amazonian margin offers a mechanism to account for the cessation of the $>600$ Ma period in the Grand Manan Island and New River belts. Under-thrusting of a buoyant oceanic ridge following such a collision will shallow the angle of subduction and arc activity may temporarily shut down above the flattened slab (Thorkelson and Taylor 1989; Gutscher et al. 1999). Ridge subduction under this part of Ganderia is also an attractive mechanism to explain the formation of the igneous protolith of the Brookville orthogneiss at $605 \pm 3 \mathrm{Ma}$ and subsequent metamorphism at $564 \pm 6 \mathrm{Ma}$ in the Brookville belt (Bevier et al. 1990; Collins 2002). Underthrusting of a ridge may lead to partial melting in the overlying rocks and is commonly accompanied by arching and deformation in the retroarc region of the hinterland (Espurt et al. 2007).

Arching in part of the Brookville belt thus could account for uplift of the Ashburn platformal carbonate sequence and formation of a deep-water retroarc basin off its flank into which clastic sedimentary rocks of the Martinon Formation were deposited. Erosion of volcanic and plutonic rocks in the inactive but uplifted arc or back-arc areas could have provided a source for the dominant $635 \pm 4 \mathrm{Ma}$ and $602 \pm 8 \mathrm{Ma}$ detrital zircon populations in the Martinon Formation. The significantly more juvenile $\varepsilon_{\mathrm{Nd}}$ signature of the sedimentary rocks of the Martinon Formation, compared to those of the underlying Ashburn Formation (Samson et al. 2000), can be explained by this model - the Martinon sediments contain a significant detrital component derived from erosion of the continental-margin volcanic and plutonic rocks, whereas the older Ashburn sediments were sourced entirely from evolved continental basement of the Amazonian hinterland. Outboard of the Brookville belt, sandstone of The Thoroughfare and Flagg Cove formations on Grand Manan Island, respectively exhibit evolved and more juvenile $\varepsilon_{\mathrm{Nd}}$ signatures (Hodgins 1994), suggesting that the Flagg Cove sandstone and underlying conglomerate of the Great Duck Island Formation may represent a coarser retoarc facies that overstepped the passive margin of the back-arc area bordering the Martinon basin.

Magmatic arc activity resumed in coastal New Brunswick in the later part of the Ediacaran and continued into the early part of the Early Cambrian. In the New River belt magmatic activity lasted from $\sim 553$ to $\sim 539 \mathrm{Ma}$ and on Grand Manan Island from $\sim 547$ to $\sim 535 \mathrm{Ma}$; magmatic activity was particularly long-lived in the Brookville belt where voluminous calcalkaline plutons were emplaced into the hinterland region from $\sim 553$ to $\sim 528 \mathrm{Ma}$ (Eby and Currie 1996; White and Barr 1996; Currie and McNicoll 1999; White et al. 2002; Barr et al. 2003a). This inboard onset of calc-alkaline plutonic activity can be attributed to the continued presence of a relatively shal- low subduction angle that caused the marginal arc to become compressive and encroach inboard onto thickened continental crust (Collins 2002; Kay et al. 2005). Hinterland-vergent (southward) thrusting documented in volcanic rocks of the Ingalls Head Formation on Grand Manan Island by Fyffe and Grant (2005) may be a consequence of this arc migration. This overall change in tectonic regime of the Ediacaran to Early Cambrian Ganderian arc system from extensional ( $\sim 629$ to $\sim 611 \mathrm{Ma})$ to compressional $(\sim 553$ to $\sim 528 \mathrm{Ma})$ is a typical feature in the geodynamic evoution of a convergent plate boundary with time (Dewey 1980).

Oblique subduction and eventual collision of a spreading oceanic ridge with the continental margin may have terminated this younger period of arc magmatism at $\sim 528 \mathrm{Ma}$, as proposed by Murphy and Nance (1989) for similar but older events in Avalonia, because the subducting slab will break off and transform motion will then become dominant (Michaud et al. 2006). This change from a convergent to a transform plate boundary along the northern Gondwanan continental margin may have led to the transfer of the Ganderian and Avalonian microcontinents from the Pacific Ocean to the opening Paleozoic Iapetus Ocean (Murphy and Nance 1989; van Staal et al. 1996; Nance et al. 2002; Rogers et al. 2006).

The overstepping of the platformal sequence of the Buckmans Creek "group" onto basement rocks of the New River belt suggests that the encroachment of Ganderia into the Iapetan ocean tract had occurred by the Early Cambrian (Fig. 10). The presence of a thick volcanic section of continental tholeiites in the middle part of the Buckmans Creek

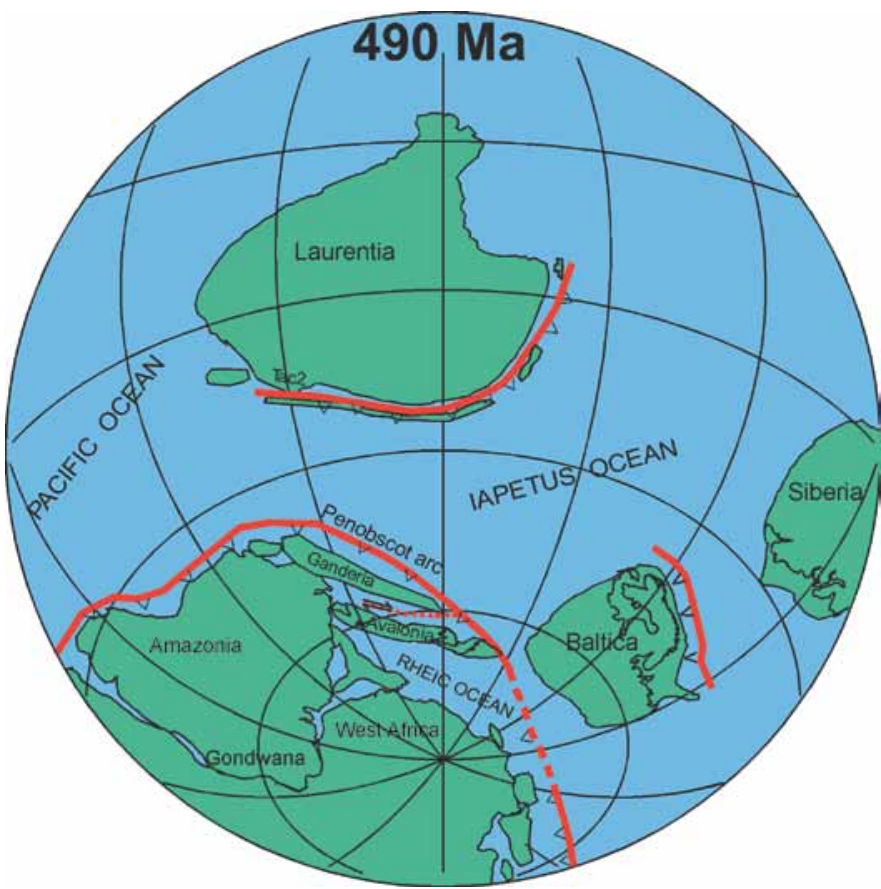

Fig. 10. Late Cambrian paleogeographic setting of Ganderia within the Iapetus Ocean (modified after van Staal et al. 1998). 
"group" indicates that extensive rifting had started along this margin by the late Early Cambrian at $\sim 520 \mathrm{Ma}$ (Greenough et al. 1985; Landing et al. 1998, 2008). The quartzose sandstone and conglomerate of the Matthews Lake Formation, shown above to overlie Neoproterozoic rocks of the New River belt and underlie volcanic rocks of the Mosquito Lake Road Formation dated at $514 \pm 2 \mathrm{Ma}$, may represent a more outboard facies of the quartzose sandstone found near the base of the Buckmans Creek "group" farther to the southwest. If correct, southern New Brunswick appears to be the only region in the Appalachian Orogen that preserves remnants of the inner and outer Paleozoic platform of Ganderia.

Neoproterozoic rocks similar to the Ragged Falls Granite (dated at $553 \pm 2 \mathrm{Ma}$ ) and associated volcanic rocks underlie the late Early Cambrian volcanic rocks of the Mosquito Lake Road Formation in the New River belt. Similar basement rocks are inferred to underlie the Middle Cambrian volcanic rocks of the Ellsworth Formation in coastal Maine on the basis of the dominant detrital zircon population $(545 \pm 4 \mathrm{Ma})$ recovered from the sample of intraformational sandstone. These late Early Cambrian volcanic sequences in New Brunswick and Maine occupy the same inboard position along the southeastern Iapetan margin as the volcanic rocks of the Bay du Nord Formation on the southern coast of Newfoundland (Dunning and O'Brien 1989; O'Brien et al. 1991; Tucker et al. 1994). All can be interpreted to have been generated in a Cambrian backarc basin that opened behind a northwesterly facing Penobscot arc represented by the 513-510 Ma Tally Pond Group in central Newfoundland (Rogers et al. 2006; Zagorevski et al. 2007; Hibbard et al. 2007).

The St. Croix belt displays stratigraphic characteristics that are for the most part quite distinct from the nearby Ellsworth, New River, and Brookville belts. Basement to the St. Croix belt, as reconstructed by Tucker et al. (2001), is likely represented by marble and quartzite of the Seven Hundred Acre Island Formation, which lithologically resembles the Ashburn Formation of the Brookville belt. However, as noted above, the Seven Hundred Acre sequence lacks evidence of having been involved in the $\sim 553$ to $\sim 528$ Ma magmatic event that affected the Brookville belt. The St. Croix belt contains a thick succession of quartzose sandstone (Crocker Hill Formation in New Brunswick $=$ Megunticook Formation in Maine) that were presumably deposited on an inactive segment of the continental margin during the rifting of Ganderia from Amazonia in the Cambrian. In contrast, the presently adjoining Ellsworth and New River belts was apparently formed along an active part of this same margin as indicated by the presence of a late Early to Middle Cambrian volcanic arc. However, the inactive and active segments of the margin were also apparently proximal enough to each other for erosion of the Neoproterozoic arc system of the Ellsworth and New River belts to provide detritus to the Calais black shale sequence of the St. Croix belt.

The proximal nature of the of the St. Croix belt to the Ellsworth and New River belts is supported by some notable lithological similarities. Mafic volcanic flows and tuff dated at $503 \pm 4 \mathrm{Ma}$ (Tucker et al. 2001), which occur at the base of the black shale sequence that defines the Calais Formation of the St. Croix belt, have MORB-like geochemistry similar to that of mafic volcanic rocks of the Castine Formation dated at $502 \pm 4 \mathrm{Ma}$ in the adjacent Ellsworth belt (Schultz et al. 2008). Moreover, Middle Cambrian black shale at the top of the stratigraphic section of the Buckmans Creek "group" is consistent with the New River and St. Croix belts being located along the same transgressive oceanic margin at that time.

Juxtaposition of the St. Croix belt against the Ellsworth and New River belts likely took place by dextral displacement along the Turtle Head fault as a result of the oblique collision between Ganderia and Laurentia in the Silurian (Stewart et al. 1995; van Staal 2007; Wintsch et al. 2007; van Staal et al. 2008). Dextral displacement appears to have also resulted in the removal of much of the arc and all the forearc region of the Penobscot arc in southern New Brunswick and coastal Maine. It is interesting to note that the evolution of Cambrian volcanic arc system in the New River and Ellsworth belts is more closely related in time to development of the Tally Pond arc in central Newfoundland than to the adjacent St. Croix and Miramichi belts.

Evidence for some Penobcot arc activity does exist in the Miramichi belt near Bathurst in northern New Brunswick, where volcanic clasts and a rhyolite flow dated at $479 \pm 6$ $\mathrm{Ma}$ are present in sandstone of the Patrick Brook Formation in the uppermost part of the Miramichi Group (Fyffe et al. 1997; McNicoll et al. 2002). Conglomerate of Vallée Lourdes Formation overlying the Patrick Brook Formation marks the Penobcsot unconformity at the base of the Tetagouche Group. No such unconformity is apparent in the southern part of the Miramichi belt where post-Penobscot arc volcanics of the Meductic Group appear to lie conformably above Cambrian to Early Ordovician sedimentary rocks of the Woodstock Group (Fyffe et al. 1983; Fyffe 2001). Therefore, it is likely that the Meductic arc and Tetagouche back-arc volcanic activity is related to the extensional evolution of the northwest-facing postPenobscot Popelogan arc in northwestern New Brunwick (van Staal and Fyffe 1995a, b; van Staal et al. 1996, 1998, 2008).

\section{CONCLUSIONS}

The possible age range of deposition for sampled conglomerate and sandstone units from New Brunswick and coastal Maine - based on a maximum limit constrained by the youngest statistical detrital zircon age populations and on a minimum limit constrained by stratigraphic, paleontological, and cross-cutting intrusive relationships - are as follows: Martinon Formation from $602 \pm 8$ to $546 \pm 2 \mathrm{Ma}$, the age of the cross-cutting Ludgate Lake Granodiorite; Flagg Cove Formation from $574 \pm 7$ to $535 \pm 3 \mathrm{Ma}$, the age of the cross-cutting Stanley Brook Granite; Matthews Lake Formation from $539 \pm 5$ to 514 $\pm 2 \mathrm{Ma}$, the age of overlying volcanic rocks in the Mosquito Lake Road Formation; Ellsworth Formation from $507 \pm 6$ to $509 \pm 1 \mathrm{Ma}$, the age of magmatic zircons from intraformational felsic tuff; Calais Formation from $510 \pm 8$ to $479 \pm 2 \mathrm{Ma}$, based 
on contained Arenigian graptolites; and Baskahegan Lake Formation from $525 \pm 6$ to $488 \pm 2 \mathrm{Ma}$, based on Tremadocian graptolites in overlying black shale of the Bright Eye Brook Formation (Fig. 3).

The relatively young Neoproterozoic age indicated for Martinon Formation of the Brookville belt is consistent with the earlier interpretation that it lies unconformably on platformal carbonates of the Ashburn Formation, which could be as old as Mesoproterozoic based on the presence of stomatolites and previous detrital zircon results. The progressive younger depositional ages of the quartzose sandstone sequences of the Brookville belt (Martinon Formation), Grand Manan Island belt (Flagg Cove Formation) and New River belt (Matthews Lake Formation) can be attributed to episodic periods of quiescence and arc activity along the convergent margin of Ganderia.

The dominant zircon age population in the Ellsworth sample has an age of $545 \pm 4$ Ma indicating that Middle Cambrian volcanic rocks of the Ellsworth and Castine formations in coastal Maine likely lie on the same Neoproterozoic volcanic and plutonic basement rocks as the late Early Cambrian volcanic rocks of the Mosquito Lake Road Formation in the New River belts of New Brunswick. The quartzose sandstone and conglomerate of the Matthews Lake Formation, shown to directly overlie New River basement on the basis of detrital zircon content, apparently represent a deeper water facies of the platformal quartzose sandstone found near the base of the Cambrian Buckmans Creek "group" lying with faulted unconformity on New River basement farther to the southwest. Southern New Brunswick may, therefore, be the only region in the Appalachian Orogen where the transition from platformal to deeper water sedimentary facies characteristic of Ganderia is preserved.

The igneous rocks of the Brookville, Grand Manan Island, and New River belts possess similar negative $\varepsilon_{\mathrm{Nd}}$ signatures suggesting that the volcanic and plutonic rocks in these belts were derived from a similar source containing a component of highly evolved continental crust. Mesoproterozoic detrital zircon grains in the range from 1.6 to $1.2 \mathrm{Ga}$ and lack of Paleoproterozoic grains in the range 2.5 to $2.3 \mathrm{Ga}$ in sedimentary samples from these Ganderian belts is consistent with an origin along the peri-Gondwanan margin of the Amazonia rather than West Africa. The Grand Manan and New River belts both record two distinct periods of Neoproterozoic arc magmatism along this margin at $\sim 629$ to $\sim 611 \mathrm{Ma}$ and at $\sim 553$ to $\sim 535 \mathrm{Ma}$.

The carbonate succession of the Brookville belt is interpreted to represent the hinterland interior of the Amazonian craton lying inboard of the Grand Manan back-arc basin and New River arc system. Uplift of the Brookville carbonate platform and development of the Martinon retroarc basin may have been related to subduction of an aseismic oceanic ridge that resulted in shallowing of the subduction angle and temporary cessation of the older period of arc activity. Migration of younger arc magmatism toward the hinterland region of the Brookville belt suggests that the angle of subduction angle remained shallow into the later part of the Neoproterozoic. Termination of this younger period of arc activity is attributed to collision of a spreading oceanic ridge with the continental margin in the Early Cambrian.

Back-arc volcanic activity related to development of a Cambrian Penobscot arc system occurred along the peri-Gondwanan margin of Iapetus between the late Early to Middle Cambrian in the New River and Ellsworth belts of southern New Brunswick and coastal Maine. Rifting of the MeducticPopelogan arc along the outboard margin of Ganderia led to a period of Ordovician back-arc volcanic activity in the Miramichi belt of central and northern New Brunswick.

\section{ACKNOWLEDGEMENTS}

Staff of the geochronology laboratory at the Geological Survey of Canada are thanked for their assistance in the preparation of the samples for analysis. Spike Berry of the Maine Geological Survey provided the geology map of the Ellsworth area. Terry Leonard and Erin Smith of the New Brunswick Minerals, Policy and Planning Division prepared the map figures. Fieldwork by Sandra Barr in southern New Brunswick has been funded in part by Natural Sciences and Engineering Research Council Discovery grants and by the New Brunswick Department of Natural Resources. Journal reviewers Brendan Murphy and Scott Samson are thanked for their advice on improving the original version of the manuscript.

\section{REFERENCES}

Alcock, F.J. 1938. Geology of Saint John region, New Brunswick. Canada Department of Mines and Resources, Mines and Geology Branch, Geological Survey of Canada, Memoir 216, $65 \mathrm{p}$.

Alcock, F.J. 1948. Grand Manan, New Brunswick. Geological Survey of Canada, Map 965A (with marginal notes), scale $1: 63360$.

Barr, S.M., and Raeside, R.P. 1989. Tectono-stratigraphic terranes in Cape Breton Island, Nova Scotia.implications for the configuration of the northern Appalachian orogen. Geology 17, pp. 822-825. doi:10.1130/00917613(1989)017<0822:TSTICB >2.3.CO;2

Barr, S.M., and White, C.E. 1996. Contrasts in late Precambrian-early Paleozoic tectonothermal history between Avalon Composite Terrane sensu stricto and other periGondwanan terranes in southern New Brunswick and Cape Breton Island, Canada. In Avalonian and Related PeriGondwanan Terranes of the Circum-North Atlantic. Edited by R.D. Nance and M.D. Thompson. Geological Society of America, Special Paper 304, pp. 95-108.

Barr, S.M., Raeside, R.P., and White, C.E. 1998. Geological correlations between Cape Breton Island, Nova Scotia and 
Newfoundland, northern Appalachian orogen. Canadian Journal of Earth Sciences 35, pp. 1252-1270. doi:10.1139/ cjes-35-11-1252

Barr, S.M., White, C.E., and Miller, B.V. 2002. The Kingston Terrane, southern New Brunswick, Canada: Evidence for a Silurian volcanic arc. Geological Society of America, Bulletin 114, pp. 964-982. doi:10.1130/00167606(2002)114<0964:TKTSNB >2.0.CO;2

Barr, S.M., White, C.E., and Miller, B.V. 2003a. Age and geochemistry of Late Neoproterozoic and Early Cambrian igneous rocks in southern New Brunswick: Similarities and contrasts. Atlantic Geology 39, pp. 55-73.

Barr, S.M., Miller, B.V., Fyffe, L.R., and White, C.E. 2003 b. New U-Pb ages from Grand Manan and the Wolves islands, southern New Brunswick. In Current Research 2002. Edited by B.M.W. Carroll. New Brunswick Department of Natural Resources; Minerals, Policy and Planning Division, Mineral Resource Report 2003-4, pp. 13-22.

Barr, S.M., Davis, D.W., Kamo, S., and White, C.E. 2003c. Significance of U-Pb detrital zircon ages in quartzite from peri-Gondwanan terranes, New Brunswick and Nova Scotia, Canada. Precambrian Research 126, pp. 123-145. doi:10.1016/S0301-9268(03)00192-X

Bartsch, C. J., and Barr, S. M. 2005. Distribution and petrochemistry of Late Neoproterozoic rocks in the southwestern New River Terrane, southern New Brunswick. In Geological Investigations in New Brunswick for 2004. Edited by G. L. Martin. New Brunswick Department Natural Resources; Minerals, Policy and Planning Division, Mineral Resource Report 2005-1, pp. 1-22.

Bevier, M.L., White, C.E., and Barr, S.M. 1990. Late Precambrian U-Pb ages for the Brookville Gneiss, southern New Brunswick. Journal of Geology 98, pp. 53-63. doi:10.1086/629374

Bevier, M.L., Barr, S.M., White, C.E., and McDonald, A.S. 1993. U-Pb geochronological constraints on the volcanic evolution of the Mira (Avalon) terrane, southeastern Cape Breton Island, Nova Scotia. Canadian Journal of Earth Sciences 30, pp. 1-10. doi:10.1139/e93-001

Black R. S., Barr, S. M., Fyffe, L. R., and Miller, B. V. 2004. PreMesozoic rocks of Grand Manan Island, New Brunswick: Field relationships, new U-Pb ages, and petrochemistry. In Geological Investigations in New Brunswick for 2003. Edited by Gwen L. Martin. New Brunswick Department of Natural Resources; Minerals, Policy and Planning Division, Mineral Resource Report 2004-4, pp. 21-40.

Collins, W. J. 2002. Hot orogens, tectonic switching, and creation of continental crust. Geology 30, pp. 535-538. doi:10.1130/0091-7613(2002)030<0535:HOTSAC $>2.0$ $\mathrm{CO} ; 2$

Compston, W., Williams, S., Kirschvink, J.L., Zichao, Z., and Guogan Ma. 1992. Zircon U-Pb ages for the Early Cambrian time-scale. Journal of the Geological Society, London, 149, pp. 171-184. doi:10.1144/gsigs.149.2.0171

Currie, K.L. 1986. The stratigraphy and structure of the Avalo- nian terrane around Saint John, New Brunswick. Maritime Sediments and Atlantic Geology 22, pp. 278-295.

Currie, K.L. 1991. A note on the stratigraphy and significance of the Martinon Formation, Saint John, New Brunswick. In Current Research, Part D. Geological Survey of Canada, Paper 91-1D, pp. 9-13.

Currie, K.L., and Hunt, P.A. 1991. Latest Precambrian igneous activity near Saint John, New Brunswick. In Radiogenic Age and Isotopic Studies: Report 4. Geological Survey of Canada, Paper 90-2, pp. 11-17.

Currie, K.L., and McNicoll, V.J. 1999. New data on the age and geographic distribution of Neoproterozoic plutons near Saint John, New Brunswick. Atlantic Geology 35, pp.157166.

Dallmeyer, R.D., Doig, R., Nance, R.D., and Murphy,J.B. 1990. ${ }^{40} \mathrm{Ar} /{ }^{39} \mathrm{Ar}$ and U-Pb mineral ages from the Brookville Gneiss and Green Head Group: implications for terrane analysis and evolution of Avalonian "basement" in southern New Brunswick. Atlantic Geology 26, pp. 247-257.

David, J., Gariepy, C., and Philippe, S. 1991. Lower Paleozoic tholeiitic dykes from central New Brunswick: possible evidence for the early opening of an ensialic Taconian back-arc basin. Canadian Journal of Earth Sciences 28, pp. 14441454.

Dewey, J.F. 1980. Episodicity, sequence, and style at convergent plate boundaries. In The Continental Crust and its Mineral Deposits. Edited by D.W. Strangway. Geology Association of Canada, Special Paper 20, pp. 553-573.

Donohoe, H.V. 1973. Acadian Orogeny in coastal southern New Brunswick. In Geology of New Brunswick, Field Guide to Excursions, Edited by N. Rast. New England Intercollegiate Geological Conference, pp. 71-80.

Dostal, J. 1989. Geochemistry of Ordovician volcanic rocks of the Tetagouche Group of southwestern New Brunswick. Atlantic Geology 25, pp. 199-209.

Dunning, G. R., and O'Brien, S. J. 1989. Late Proterozoic-Early Paleozoic crust in the Hermitage Flexture, Newfoundland Appalachians: $\mathrm{U} / \mathrm{Pb}$ ages and tectonic significance. Geology 17,pp.548-551.doi:10.1130/0091-7613(1989)017<0548:LP EPCI $>2.3 . \mathrm{CO} ; 2$

Eby, G.N., and Currie, K.L. 1993. Petrology and geochemistry of the Kingston complex - a bimodal sheeted dyke suite in southern New Brunswick. Atlantic Geology 29, pp. 121-135.

Eby, G.N., and Currie, K.L. 1996. Geochemistry of the granitoid plutons of the Brookville terrane, Saint John, New Brunswick and implications for the development of the Avalon Zone. Atlantic Geology 32, pp. 247-268.

Espurt, N., Baby, P., Brusset, S., Roddaz, M., Hermoza, W., Regard, V., Antoine, P-O., Salas-Gismondi, R., and Bolaños, R. 2007. How does the Nazca Ridge subduction influence the modern Amazonian foreland. Geology 35, pp. 515-518. doi:10.1130/G23237A.1

Fyffe, L.R. 1976. Correlation of geology in the southwestern and northern parts of the Miramichi Zone. In $139^{\text {th }}$ Annual Report of the Department of Natural Resources of the 
Province of New Brunswick for the year ended 31st March 1976. The Government of the Province of New Brunswick, Fredericton, pp. 137-141.

Fyffe, L.R. 1995. Fredericton Belt. In chapter 4 of Geology of the Appalachian-Caledonian Orogen in Canada and Greenland. Geological Survey of Canada, Geology of Canada, No. 6, pp. 351-354.

Fyffe, L.R. 2001. Stratigraphy and geochemistry of Ordovician volcanic rocks of the Eel River area, west-central New Brunswick. Atlantic Geology 37, pp. 81-101.

Fyffe, L.R., and Fricker, A. 1987. Tectonostratigraphic terrane analysis of New Brunswick. Maritime Sediments and Atlantic Geology 23, pp. 113-122.

Fyffe, L.R., and Grant, R.H. 2001. Precambrian and Paleozoic geology of Manan Island: The Ganderian margin of Iapetus. In Guidebook of Field Trips in New Brunswick and Eastern Maine. Edited by D.R. Lentz and R.K. Pickerill. 93rd Annual Meeting of New England Intercollegiate Geological Conference, University of New Brunswick, Fredericton, New Brunswick, pp. A5-1-A5-13.

Fyffe, L.R., and Grant, R.H. 2005. Bedrock geology of Grand Manan Island, New Brunswick (parts of $21 \mathrm{~B} / 10$ and B/15), New Brunswick Department of Natural Resources, Map Plate 2005-24, scale 1:20 000.

Fyffe, L.R., and Riva. J. 2001. Revised stratigraphy of the Cookson Group of southwestern New Brunswick and adjacent Maine. Atlantic Geology 26, pp. 271-276.

Fyffe, L.R., and Riva. J. 2001. Regional significance of graptolites from the Digdeguash Formation of southwestern New Brunswick. In Current Research 2000. Edited by B.M.W. Carroll. New Brunswick Department of Natural Resources and Energy; Minerals, Policy and Planning Division, Mineral Resource Report 2001-4, pp. 47-54.

Fyffe, L.R., Forbes, W.H., and Riva, J. 1983. Graptolites from the Benton area of west-central New Brunswick and their regional significance. Maritime Sediments and Atlantic Geology 19, pp. 117-125.

Fyffe, L.R., Stewart, D.B., and Ludman, A. 1988. Tectonic significance of black pelites and basalt in the St. Croix terrane, coastal Maine and southern New Brunswick. Maritime Sediments and Atlantic Geology 24, pp. 281-288.

Fyffe, L.R., McCutcheon, S.R., and Wilson, R.A. 1997. Miramichi-Tetagouche stratigraphic relationships, Bathurst Mining Camp, northern New Brunswick. In Current Research 1996. Edited by B.M.W. Carroll. New Brunswick Department of Natural Resources and Energy, Minerals and Energy Division, Mineral Resource Report 97-4, pp. 37-51.

Fyffe, L.R., Pickerill, R.K., and Stringer, P. 1999. Stratigraphy, sedimentology and structure of the Oak Bay and Waweig formations, Mascarene basin: Implications for the Paleotectonic evolution of southwestern New Brunswick. Atlantic Geology 35, pp. 59-84.

Gates, O. 1969. Lower Silurian-Lower Devonian volcanic rocks of New England coast and southern New Brunswick. In North Atlantic - Geology and Continental Drift, Edited by M. Kay. American Association of Petroleum Geologists, Memoir 12, pp. 484-503.

Gates, O. 1989. Silurian roundstone conglomerates of coastal Maine and adjacent New Brunswick. In Studies in Maine Geology. Edited by R.D. Tucker and R.G. Marvinney. Maine Geological Survey, Volume 2: Structure and Stratigraphy, pp. 127-144.

Gradstein, F.M., Ogg, J.G., and Smith, A.G. 2004. A geologic time scale. Cambridge University Press, Cambridge, $384 \mathrm{p}$.

Greenough, J.D., McCutcheon, S.R., and Papezik, V.S. 1985. Petrology and geochemistry of Cambrian volcanic rocks from the Avalon Zone in New Brunswick. Canadian Journal of Earth Sciences 22, pp. 881-892.

Gutscher, M-A., Malavielle, J., Lallemand, S., and Collot, J-Y. 1999. Tectonic segmentation of the North Andean margin: impact of the Carnegie Ridge Collision. Earth and Planetary Science Letters 168, pp. 255-270. doi:10.1016/S0012821X(99)00060-6

Helmstaedt, H. 1968. Structural analysis of the Beaver Harbour area, Charlotte County, New Brunswick. Unpublished Ph.D. thesis, University of New Brunswick, Fredericton, New Brunswick, 196 p.

Hibbard, J.P., van Staal, C.R. and Rankin, D.W., and Williams, H. 2006. Lithotectonic map of the Appalachian Orogen (North), Canada-United States of America; Geological Survey of Canada, Map 02042A, scale 1:1500 000.

Hibbard, J.P., van Staal, C.R., and Rankin, D.W. 2007. A comparative analysis of pre-Silurian crustal building blocks of the northern and southern Appalachian orogen. American Journal of Science 307, pp. 23-45. doi:10.2475/01.2007.02

Hodgins, M.L. 1994. Trace element, REE, and Nd isotopic variations in metavolcanic and metasedimentary sequences, Grand Manan Island, New Brunswick. Unpublished B. Sc. thesis, Department of Geology, Hartwick College, Oneonta, New York, 43 p.

Hofmann, H. J. 1974. The stromatolite Archaeozoon acadiense from the Proterozoic Greenhead Group of Saint John, New Brunswick. Canadian Journal of Earth Sciences 11, pp. 1098-1115. doi:10.1139/e74-105

Johnson, S.C. 2001. Contrasting geology in the Pocologan River and Long Reach areas: implications for the New River belt and correlations in southern New Brunswick and Maine. Atlantic Geology 37, pp.61-79.

Johnson, S. C., and Barr, S. M. 2004. New chemical data from Neoproterozoic-Cambrian igneous rocks in the Long Reach area, southern New Brunswick. In Geological Investigations in New Brunswick for 2003. Edited by Gwen L. Martin. New Brunswick Department of Natural Resources; Minerals, Policy, and Planning Division, Mineral Resource Report 20044, pp. 75-94.

Johnson, S.C., and McLeod, M.J. 1996. The New River Belt: A unique segment along the western margin of the Avalon composite terrane, southern New Brunswick, Canada. In Avalonian and related peri-Gondwanan terranes of the Circum-North Atlantic. Edited by R.D. Nance and M.D. 
Thompson. Geological Society of America, Special Paper 304, pp. 149-164.

Kay, S.M., Godoy, E., and Kurtz, A. 2005. Episodic arc migration, crustal thickening, subduction erosion and magmatism in the south-central Andes. Geological Society of America, Bulletin 117, pp. 67-88. doi:10.1130/B25431.1

Keppie J.D., Murphy, J.B., and Nance, R.D. 1996. Terrane transfer between eastern Laurentia and western Gondwana in the early Paleozoic: Constraints on global reconstructions. In Avalonian and Related peri-Gondwanan Terranes of the Circum-North Atlantic. Edited by R.D. Nance and M.D. Thompson. Geological Society of America, Special Paper 304, pp. 369-380.

Keppie J.D., Davis, D.W., and Krogh, T.E. 1998. U-Pb geochronological constraints on Precambrian stratified units in the Avalon composite terrane of Nova Scotia, Canada. Tectonic implications. Canadian Journal of Earth Sciences 35, pp. 222-236. doi:10.1139/cjes-35-3-222

Landing, E., Bowring, S.A., Davidek, K.L., Westrop, S.R., Geyer, G., and Heldmaier, W. 1998. Duration of the Early Cambrian: U-Pb ages of volcanic ashes from Avalon and Gondwana. Canadian Journal of Earth Sciences 35, pp. 329-338. doi:10.1139/cjes-35-4-329

Landing, E., Johnson, S.C., and Geyer, G. 2008. Faunas and Cambrian volcanism on the Avalonian marginal platform, southern New Brunswick. Journal of Paleontology 82, pp. 884-905. doi:10.1666/07-007.1

Leavitt, E.M. 1963. Geology of the Precambrian Green Head Group in the Saint John, New Brunswick area. Unpublished M.Sc. thesis, University of New Brunswick, Fredericton, New Brunswick, 146 p.

Lin, S., van Staal, C.R., and Dube, B. 1994. Promontory-promontory collision in the Canadian Appalachians. Geology 22, pp. 897-900. doi:10.1130/0091-7613(1994)022<0897:PPC ITC $>2.3 . \mathrm{CO} ; 2$

Lin, S., Davis, D.W., Barr, S.M., van Staal, C.R., Chen, Y., and Constantin, M. 2007. U-Pb geochronological constraints on the evolution of the Aspy terrane, Cape Breton Island: Implications for relationships between Aspy and Bras d'Or terranes and Ganderia in the Canadian Appalachians. American Journal of Science 307, pp. 371-398. doi:10.2475/02.2007.03

Ludman, A. 1987. Pre-Silurian stratigraphy and tectonic significance of the St. Croix Belt, southeastern Maine. Canadian Journal of Earth Sciences 24, pp. 2459-2469.

Ludman, A. 1991. Revised stratigraphy of the Cookson Group in eastern Maine and southwestern New Brunswick: an alternate view. Atlantic Geology 27, pp. 49-55.

Mann, P., Hempton, M.R., Bradley, D.C., and Burke, K. 1983. Development of pull-apart basins. Journal of Geology 91, pp. 529-554. doi:10.1086/628803

McLeod, M.J. 1995. Bedrock geology and metallic mineral occurrences in the Letang Head Harbour Passage area, Charlotte County, New Brunswick. In Current Research 1994. Compiled and Edited by S.A.A. Merlini. New Brunswick De- partment of Natural Resources and Energy, Minerals and Energy Division, Miscellaneous Report 18, pp. 141-156.

McLeod, M.J., and Rast, N. 1988. Correlations and fault systematics in the Passamaquoddy Bay area, southwestern New Brunswick. Maritime Sediments and Atlantic Geology 24, pp. 289-300.

McLeod, M.J., Ruitenberg, A.A., and Krogh, T.E. 1992. Geology and U-Pb geochronology of the Annidale Group, southern New Brunswick: Lower Ordovician volcanic and sedimentary rocks formed near the southeastern margin of Iapetus Ocean. Atlantic Geology 28, pp. 181-192.

McLeod M.J., Winchester, J.A., and Ruitenberg, A.A. 1994. Geochemistry of the Annidale Group: implications for the tectonic setting of Lower Ordovician volcanism in southwestern New Brunswick. Atlantic Geology 30, pp. 87-94.

McLeod, M.J., Pickerill, R.K., and Lux, R.D. 2001. Mafic intrusions on Campobello Island: implications for New Brunswick-Maine correlations. Atlantic Geology 37, pp. 17-40.

McLeod, M.J., Johnson, S.C., and Krogh, T.E. 2003. Archived $\mathrm{U}-\mathrm{Pb}$ (zircon) dates from southern New Brunswick. Atlantic Geology 39, pp. 209-225.

McNicoll, V.J. Van Staal, C.R., Lentz, D., and Stern, R. 2002. Uranium-lead geochronology of Middle River rhyolite: implications for the provenance of basement rocks of the Bathurst Mining Camp, New Brunswick; Radiogenic Age and Isotopic Studies: Report 15. Geological Survey of Canada, Current Research 2002-F9, 11 p.

Michaud, F., Royer, J.Y., Bourgois, J., Dyment, J., Calmus, T., Bandy, W., Sosson, M., Morteral-Gutiérrez, C., Sichler, B., Rebolledo-Viera, M., and Pontoise, B. 2006. Ocean ridge subduction vs. slab break off: Plate tectonic evolution along the Baja California Sur continental margin since $15 \mathrm{Ma}$. Geology 34, pp. 13-16. doi:10.1130/g22050.1

Miller, B.V., and Fyffe, L.R. 2002. Geochronology of the Letete and Waweig formations, Mascarene Group, southwestern New Brunswick, Atlantic Geology 38, pp. 29-36.

Miller, B.V., Barr, S.M., and Black, R.S. 2007. Neoproterozoic and Cambrian U-Pb (zircon) ages from Grand Manan Island, New Brunswick: Implications for stratigraphy and northern Appalachian terrane correlations. Canadian Journal of Earth Sciences 44, pp. 911-923. doi:10.1139/E06-132

Murphy, J.B., and Nance, R.D. 1989. Model for the evolution of the Avalonian - Cadomian belt. Geology 17, pp. 735738. doi:10.1130/0091-7613(1989)017<0735:MFTEOT $>2$ .3.CO;2

Murphy, J.B., Strachan, R.A., Nance, RD., Parker, K.D., and Fowler, M.B. 2000. Proto-Avalonia: A $1.2-1.0 \mathrm{Ga}$ tectonothermal event and constraints for the evolution of Rodinia. Geology 28, pp. 1071-1074. doi:10.1130/00917613(2000)28<1071:PAGTEA >2.0.CO;2

Nance, R.D. 1987. Model for the Precambrian evolution of the Avalon Terrane in southern New Brunswick. Geology 15, pp. 753-756. doi:10.1130/0091-7613(1987)15<753:MFT PEO >2.0.CO;2

Nance, R.D., and Murphy, J.B. 1994. Contrasting basement 
isotopic signatures and the palinspathic restoration of peripheral orogens: Example from the Neoproterozoic Avalonian - Cadomian belt. Geology 22, pp. 617-620. doi:10.1130/0091-7613(1994)022<0617:CBISAT >2.3.CO;2

Nance, R.D., Murphy, J.B., and Keppie J.D. 2002. A Cordilleran model for the evolution of Avalonia. Tectonophysics 352, pp. 11-31. doi:10.1016/S0040-1951(02)00187-7

Nemchin, A.A, and Cawood, P.A. 2005. Discordance of the $\mathrm{U}-\mathrm{Pb}$ system in detrital zircons: Implications for provenance studies of sedimentary rocks. Sedimentary Geology 182, pp. 143-162. doi:10.1016/j.sedgeo.2005.07.011

Neuman, R.B. 1964. Fossils in Ordovician tuffs, northeastern Maine. U.S. Geological Survey, Bulletin 1181-E, 53 p.

Neuman, R.B. 1984. Geology and paleobiology of islands in the Iapetus Ocean: Review and implications. Geological Society of America, Bulletin 95, pp. 1188-1201. doi:10.1130/00167606(1984)95<1188:GAPOII $>2.0$. CO;2

O’Brien, B. H., O’Brien, S. J., and Dunning, G.R. 1991. Silurian cover, Late Precambrian-Early Ordovician basement, and the chronology of Silurian orogenesis in the Hermitage Flexture (Newfoundland Appalachians). American Journal of Science 291, pp. 760-799.

O’Brien, S.J., O’Brien, B.H., Dunning, G.R., and Tucker, R.D. 1996. Late Neoproterozoic Avalonian and related periGondwanan rocks of the Newfoundland Appalachians. In Avalonian and Related peri-Gondwanan Terranes of the Circum-North Atlantic. Edited by R.D. Nance and M.D. Thompson. Geological Society of America, Special Paper 304, pp. 9-28.

Pickerill, R.K., and Fyffe, L.R. 1999. The stratigraphic significance of trace fossils from the Lower Paleozoic Baskahegan Lake Formation near Woodstock, west-central New Brunswick. Atlantic Geology 35, pp. 215-224.

Pe-Piper, G., and Wolde, B. 2000. Geochemistry of metavolcanic rocks of the Ross Island and Ingalls Head formations, Grand Manan Island, New Brunswick. Atlantic Geology 36, pp 103-116.

Poole, W.H., and Neuman, R.B. 2003. Arenig volcanic and sedimentary strata, central New Brunswick and eastern Maine. Atlantic Geology 38, pp 109-134.

Pollock, J. 2008. Bedrock geology of the Ellsworth Quadrangle,Maine. Maine Geological Survey, Open- File Map 08-88, scale 1:24 000

Potter, J., Longstaffe, F.J., and Barr, S.M. 2008. Regional ${ }^{18} \mathrm{O}-$ depletion of Neoproterozoic igneous rocks from Avalonia, Cape Breton Island, and southern New Brunswick, Canada. Geological Society of America, Bulletin 120, pp. 347-367. doi:10.1130/B26191.1

Roddick, J.C., and Bevier, M.L. 1995. U-Pb dating of granites with inherited zircon: Conventional and ion microprobe results from two Paleozoic plutons, Canadian Appalachians. Chemical Geology 119, pp. 307-329. doi:10.1016/00092541(94)00107-I

Rogers, N., van Staal, C. R., McNicoll, J., Pollock, J., Zagorevski, A., and Whalen, J. 2006. Neoproterozoic and Cambrian arc magmatism along the eastern margin of the Victoria
Lake Supergroup: A remnant of Ganderian basement in central Newfoundland. Precambrian Research 147, pp. 329-341. doi:10.1016/j.precamres.2006.01.025

Ruitenberg, A.A. 1967. Stratigraphy, structure and metallization, Piskahegan-Rolling Dam area, northern Appalachians, New Brunswick, Canada. Leidse Geologische Mededelingen 44, pp. 79-120.

Ruitenberg, A.A., McLeod, M.J., and Krogh, T.E. 1993. Comparative metallogeny of Ordovician volcanic and sedimentary rocks in the Annidale-Shannon (New Brunswick) and Harborside-Blue Hill (Maine) areas: implications of new $\mathrm{U}-\mathrm{Pb}$ age dates. Exploration and Mining Geology 2, pp. 355-365.

Samson, S.D., Barr, S.M., and White, C.E. 2000. Nd isotopic characteristics of terranes within the Avalon Zone southern New Brunswick. Canadian Journal of Earth Sciences 37, pp. 1039-1052. doi:10.1139/cjes-37-7-1039

Schultz, K.J., Stewart, D.B., Tucker, R.D., Pollock, J.C., and Ayuso, R.A. 2008. The Ellsworth terrane, coastal Maine. Geochronology, geochemistry, and Nd-Pd isotopic compositions - Implications for the rifting of Ganderia. Geological Society of America, Bulletin 120, pp. 1134-1158. doi:10.1130/B26336.1

Sircombe, K. 2000. The usefulness and limitations of binned frequency histograms and probability density distributions for displaying absolute age data. Geological Survey of Canada, Current Research 2000-F2; Radiogenic Age and Isotopic Studies, Report 13, $11 \mathrm{p}$.

Stern, R. A. 1997. The GSC Sensitive High Resolution Ion Microprobe (SHRIMP): analytical techniques of zircon U-Th$\mathrm{Pb}$ age determinations and performance evaluation. In Radiogenic age and isotopic studies, Report 10: Geological Survey of Canada, Current Research 1997-F, pp. 1-31.

Stern, R.A., and Amelin, Y. 2003. Assessment of errors in SIMS zircon U-Pb geochronology using a natural zircon standard and NIST SRM 610 glass. Chemical Geology 197, pp. 111142. doi:10.1016/S0009-2541(02)00320-0

Stewart, D.B., and Wones, D.R. 1974. Bedrock geology of the northern Penobscot Bay area. In Geology of east-central and north-central Maine, New England Intercollegiate Geological Conference Guidebook, Edited by P.H. Osberg, University of Maine, Orono, Maine, pp. 223-239.

Stewart, D.B., Unger, J.D., and Hutchinson, D.R. 1995. Silurian history of Penobscot Bay region, Maine. Atlantic Geology 31, pp. 67-80.

Stewart, D.B., Tucker, R.D., Ayuso, R.A., and Lux, R. D. 2001. Minimum age of the Proterozoic Seven Hundred Acre Island Formation and the tectonic setting of the Islesboro Formation, Islesboro block, Maine. Atlantic Geology 37, pp. 41-59.

Thorkelson, D. J., and Taylor, R. P. 1989. Cordilleran slab windows. Geology 17, pp. 833-836. doi:10.1130/00917613(1989)017<0833:CSW>2.3.CO;2

Tucker, R.D., O'Brien, S. J., and O'Brien, B. H. 1994. Age and implications of Early Ordovician (Arenig) plutonism in the type area of the Bay du Nord Group, Dunnage Zone, 
southern Newfoundland Appalachians. Canadian Journal of Earth Sciences 31, pp. 351-357.

Tucker, R.D., Osberg, P.H., and Berry, H.N., IV. 2001. The geology of part of Acadia and the nature of the Acadian Orogeny across central and eastern Maine. American Journal of Science 301, pp. 205-260. doi:10.2475/ajs.301.3.205

Valverde-Vaquero, P., Dunning, G.R., and O’Brien, S.J. 2006. Polycyclic evolution of the Late Neoproterozoic basement in the Hermitage Flexture region (southwest Newfoundland Appalachians): New evidence from the Cinq-Cerf gneiss. Precambrian Research 148, pp. 1-18. doi:10.1016/j.precamres.2006.03.001

van Staal, C.R. 1987. Tectonic setting of the Tetagouche Group in northern New Brunswick: implications for plate tectonic models of the northern Appalachians. Canadian Journal of Earth Sciences 24, pp. 1329-1351. doi:10.1139/e87-128

van Staal, C. R. 2007. Pre-Carboniferous tectonic evolution and metallogeny of the Canadian Appalachians. In Mineral resources of Canada: A synthesis of major deposit types, district metallogeny, the evolution of geological provinces, and exploration methods. Edited by W.D. Goodfellow. Geological Association of Canada, Mineral Deposits Division, Special Publication5, pp. 793-818.

van Staal, C.R., and Fyffe, L. R. 1991. Dunnage and Gander zones, New Brunswick: Canadian Appalachian Region. New Brunswick Department of Natural Resources and Energy, Mineral Resources, Geoscience Report 91-2, 39 p.

van Staal, C.R., and Fyffe, L. R. 1995a. Gander Zone-New Brunswick. In Chapter 3 of Geology of the AppalachianCaledonian Orogen in Canada and Greenland. Edited by $\mathrm{H}$. Williams. Geology Survey of Canada, Geology of Canada No. 6, pp. 216-223.

van Staal, C.R., and Fyffe, L. R. 1995b. Dunnage Zone-New Brunswick. In Chapter 3 of Geology of the AppalachianCaledonian Orogen in Canada and Greenland. Edited by $\mathrm{H}$. Williams. Geology Survey of Canada, Geology of Canada No. 6, pp. 166-178.

van Staal, C.R., and de Roo, J.A. 1996. Mid-Paleozoic tectonic evolution of the Appalachian Central Mobile Belt in northern New Brunswick, Canada: Collision, extensional collapse, and dextral transpression. In Current Perspectives in the Appalachian-Caledonian Orogen. Edited by. J.P. Hibbard, C.R. van Staal, and P.A. Cawood. Geology Association of Canada, Special Paper 41, pp. 367-389.

van Staal, C.R., Winchester, J.A., and Bedard, J.H. 1991. Geochemical variations in Middle Ordovician volcanic rocks of the northern Miramichi Highlands and their tectonic significance. Canadian Journal of Earth Sciences 28, pp. 10311049. doi:10.1139/e91-094

van Staal, C.R., Fyffe, L.R., Langton, J.P., and McCutcheon, S.R. 1992. The Ordovician Tetagouche Group, Bathurst Camp, northern New Brunswick. Exploration and Mining Journal 2, pp. 93-103.

van Staal, C.R., Sullivan, R.W., and Whalen, J.B. 1996. Provenance and tectonic history of the Gander Zone in the Caledonian/Appalachian orogen: Implications for the ori- gin and assembly of Avalon. In Avalonian and Related periGondwanan Terranes of the Circum-North Atlantic. Edited by R.D. Nance and M.D. Thompson. Geological Society of America, Special Paper 304, pp. 347-367.

van Staal, C.R., Dewey, J.F., MacNiocaill, C., and McKerrow, W.S. 1998. The Cambrian-Silurian tectonic evolution of the northern Appalachian and British Caledonides: history of a complex, west and southwest Pacific-type segment of Iapetus. In Lyell: the Past is the Key to the Present. Edited by D.J. Blundell and A.C. Scott. Geological Society, London, Special Publication 143, pp. 199-242.

van Staal, C.R., Wilson, R.A., Rogers, N., Fyffe, L.R., Gower, S.J., Langton, J.P., McCutcheon, S.R., and Walker, J.A. 2003. A new geologic map of the Bathurst Mining Camp and surrounding areas - A product of Integrated Geological, Geochemical and Geophysical Data. In Massive Sulfide Deposits of the Bathurst Mining Camp, New Brunswick and northern Maine. Edited by W.D. Goodfellow, S.R. McCutcheon and J.M. Peter. Economic Geology, Monograph 11, pp. 61-64. van Staal, C.R., Currie, K.L, Rowbotham, G., Rogers, N., and Goodfellow, W. 2008. Pressure-temperature paths and exhumation of Late Ordovician-Early Silurian blueschists and associated metamorphic nappes of the Salinic Brunswick subduction complex, northern Appalachians. Geological Society of America, Bulletin 120, pp. 1455-1477. doi:10.1130/B26324.1

Wardle, R.J. 1978. The stratigraphy and tectonics of the Green Head Group: its relationship to Hadrynian and Paleozoic rocks, southern New Brunswick. Unpublished Ph.D. thesis, University of New Brunswick, Fredericton, New Brunswick, 294 p.

Whalen, J.B., Jenner, G.A., Currie, K.L., Barr, S.M., Longstaffe, F.J., and Hegner, E. 1994. Geochemical and isotopic characteristics of granitoids of the Avalon Zone, southern New Brunswick: possible evidence for repeated delamination events. Journal of Geology 102, pp. 269-282. doi: $10.1086 / 629670$

Whalen,_J.B., Fyffe, L.R., Longstaffe, F.J., and Jenner, G.A. 1996a. The position and nature of the Gander-Avalon boundary, southern New Brunswick, based on geochemical and isotopic data from granitoid rocks. Canadian Journal of Earth Sciences 33, pp. 129-139.

Whalen, J.B., Jenner, G.A., Longstaffe, F.J., and Hegner, E. 1996b. Nature and evolution of the eastern margin of lapetus: geochemical and isotopic constraints from Siluro-Devonian granitoid plutons in the New Brunswick Appalachians. Canadian Journal of Earth Sciences 33, pp. 140-155.

Whalen, J.B., Rogers, N., van Staal, C.R., Longtaffe, F.J., Jenner, G.A., and Winchester, J.A. 1998. Geochemical and isotopic $(\mathrm{Nd}, \mathrm{O})$ data from Ordovician felsic plutonic and volcanic rocks of the Miramichi Highlands: petrogenetic and metallogenic, implications for the Bathurst Mining Camp. Canadian Journal of Earth Sciences 35, pp. 237-252. doi:10.1139/cjes-35-3-237

White, C.E. 1996. Geology, geochronology, and tectonic evolution of the Brookville terrane, southern New Brunswick. 
Unpublished Ph.D. thesis. Dalhousie University, Halifax, Nova Scotia, Canada, 513 p.

White, C.E., and Barr, S.M. 1996, Geology of the Brookville terrane, southern New Brunswick, Canada. In Avalonian and related peri-Gondwanan terranes of the Circum-North Atlantic. Edited by R.D. Nance and M.D. Thompson. Geological Society of America, Special Paper 304, pp. 133-147.

White, C.E., Barr, S.M., Miller, B.V., and Hamilton, M.A. 2002. Granitoid plutons of the Brookville terrane, southern New Brunswick: Petrology, age, and tectonic setting. Atlantic Geology 38, pp. 53-74.

Wintsch, R.P., Aleinikoff, J.N., Walsh, G.J., Bothner, W.A., Hussey II, A.M., and Fanning, C.M. 2007. SHRIMP U-Pb evidence for a Late Silurian age of metasedimentary rocks in the Merrimack and Putman-Nashoba terranes, Eastern New England. American Journal of Science 307, pp. 119167. doi:10.2475/01.2007.05

Zagorevski, A., van Staal, C.R., McNicoll, V., and Rogers, N. 2007. Upper Cambrian to Upper Ordovician peri-Gondwanan island arc activity in the Victoria Lake Supergroup, Central Newfoundland: Tectonic development of the northern Ganderian margin. American Journal of Science 307, pp. 339-370. doi:10.2475/02.2007.02

Editorial responsibility: Simon K. Haslett 


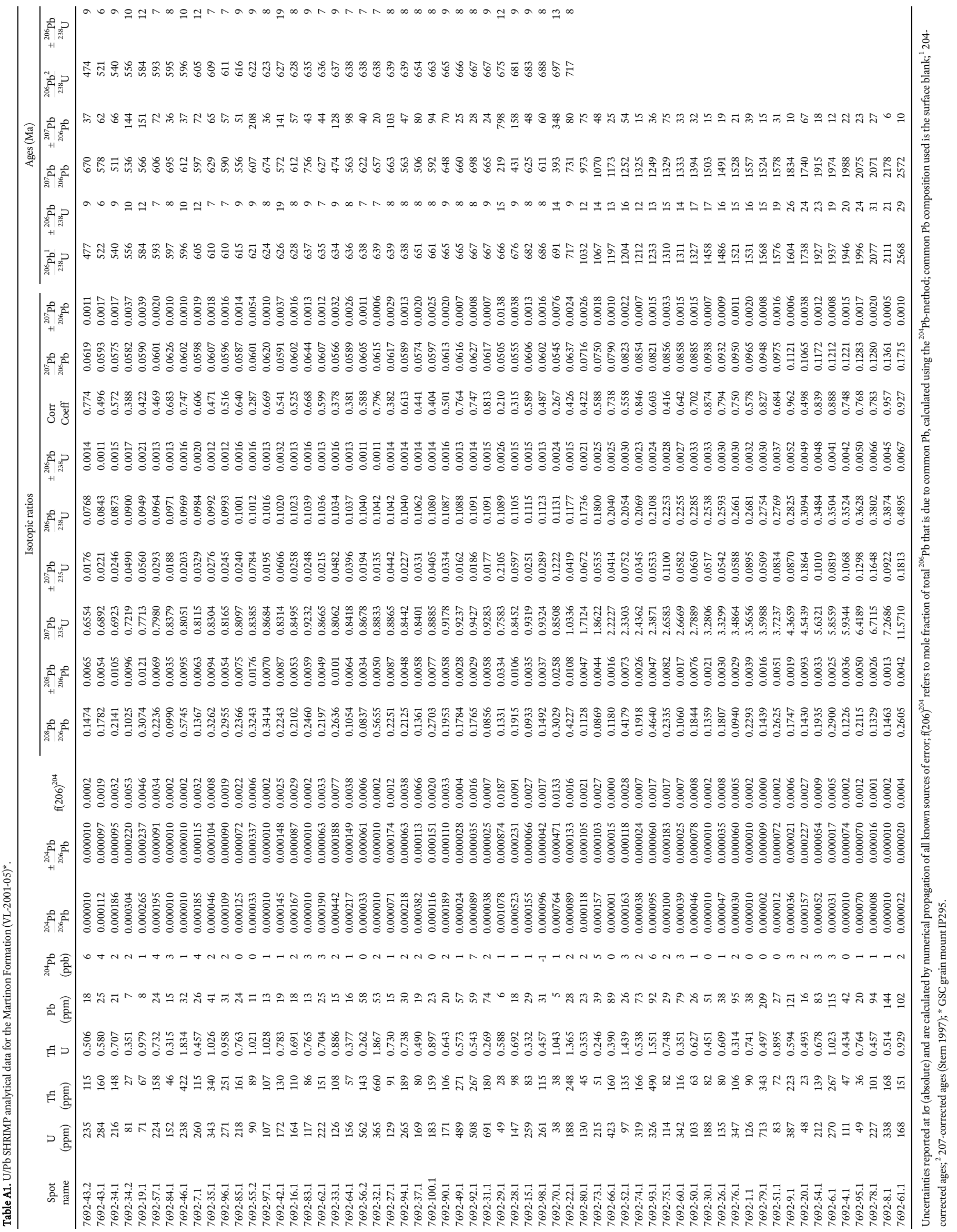




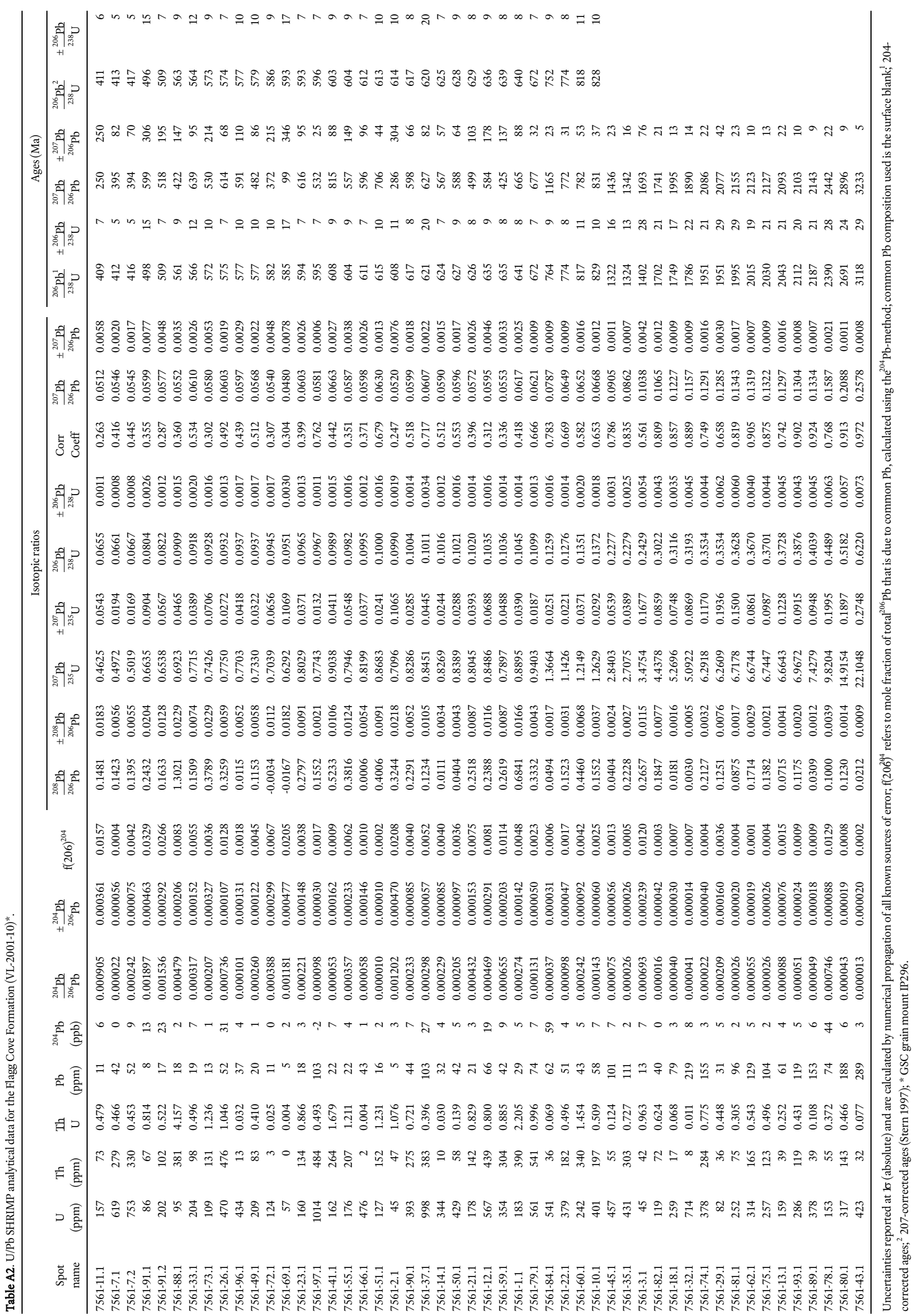




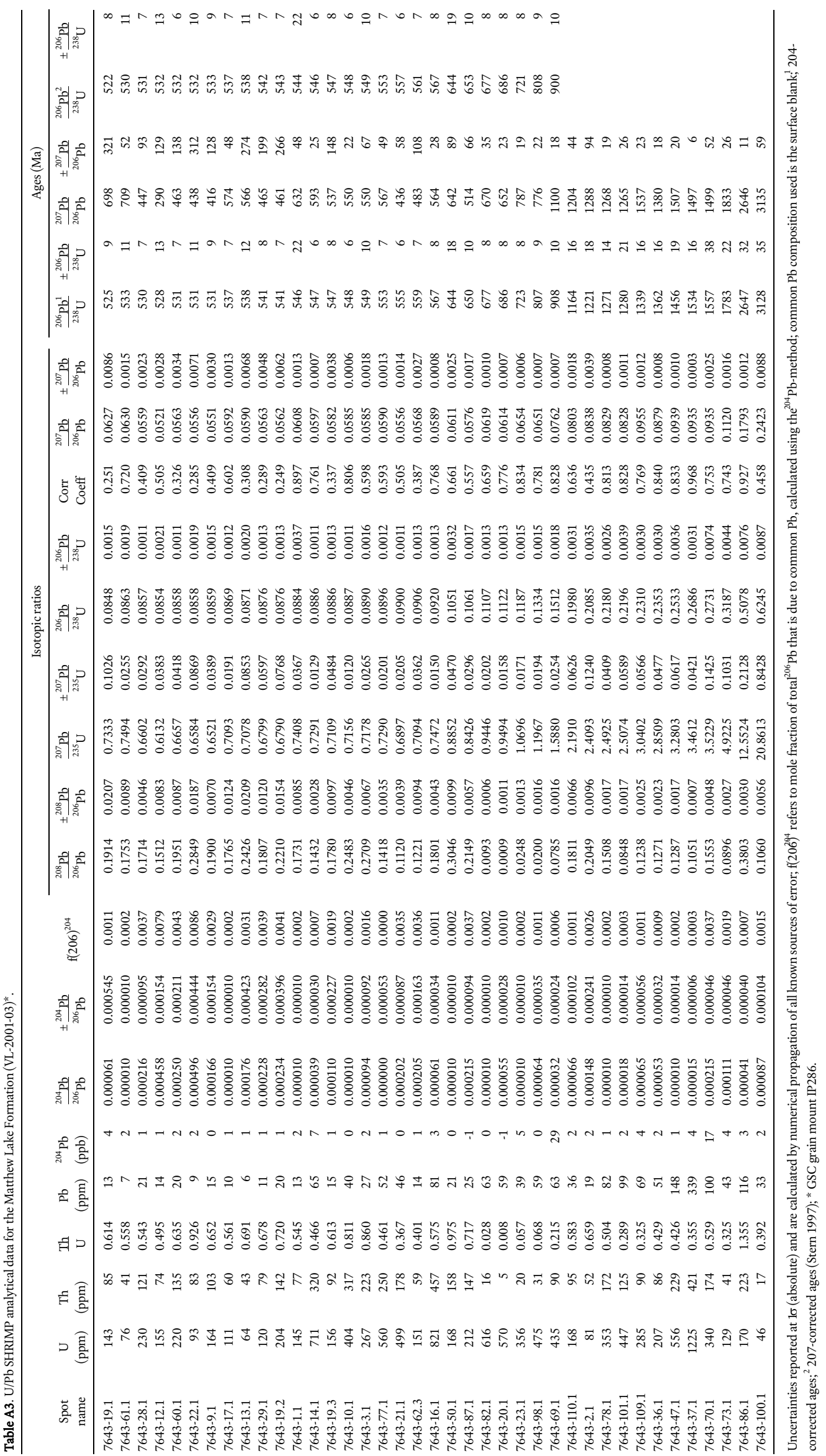




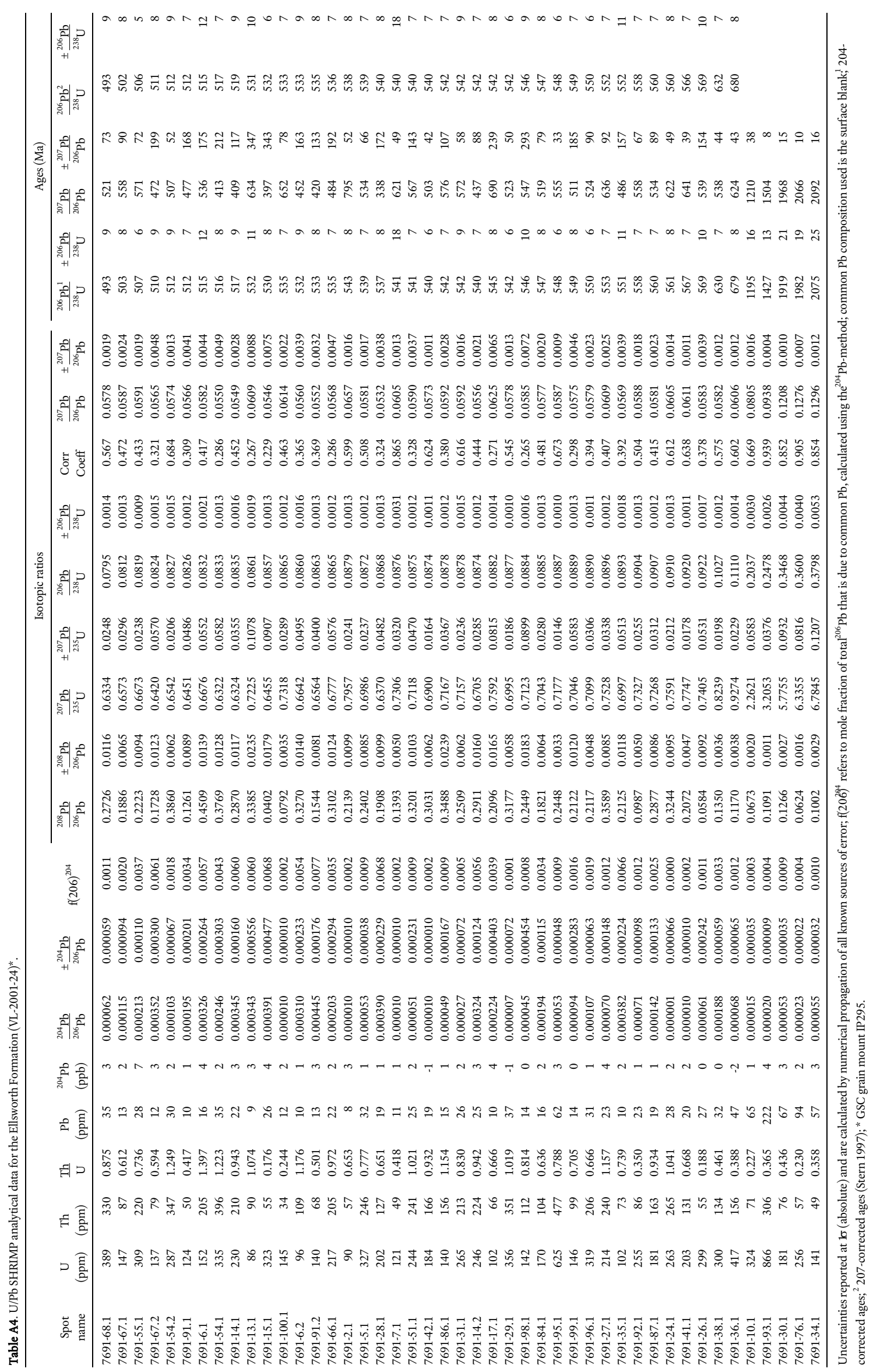


ATLANTIC GEOLOGY $\cdot$ VOLUME $45 \cdot 2009$

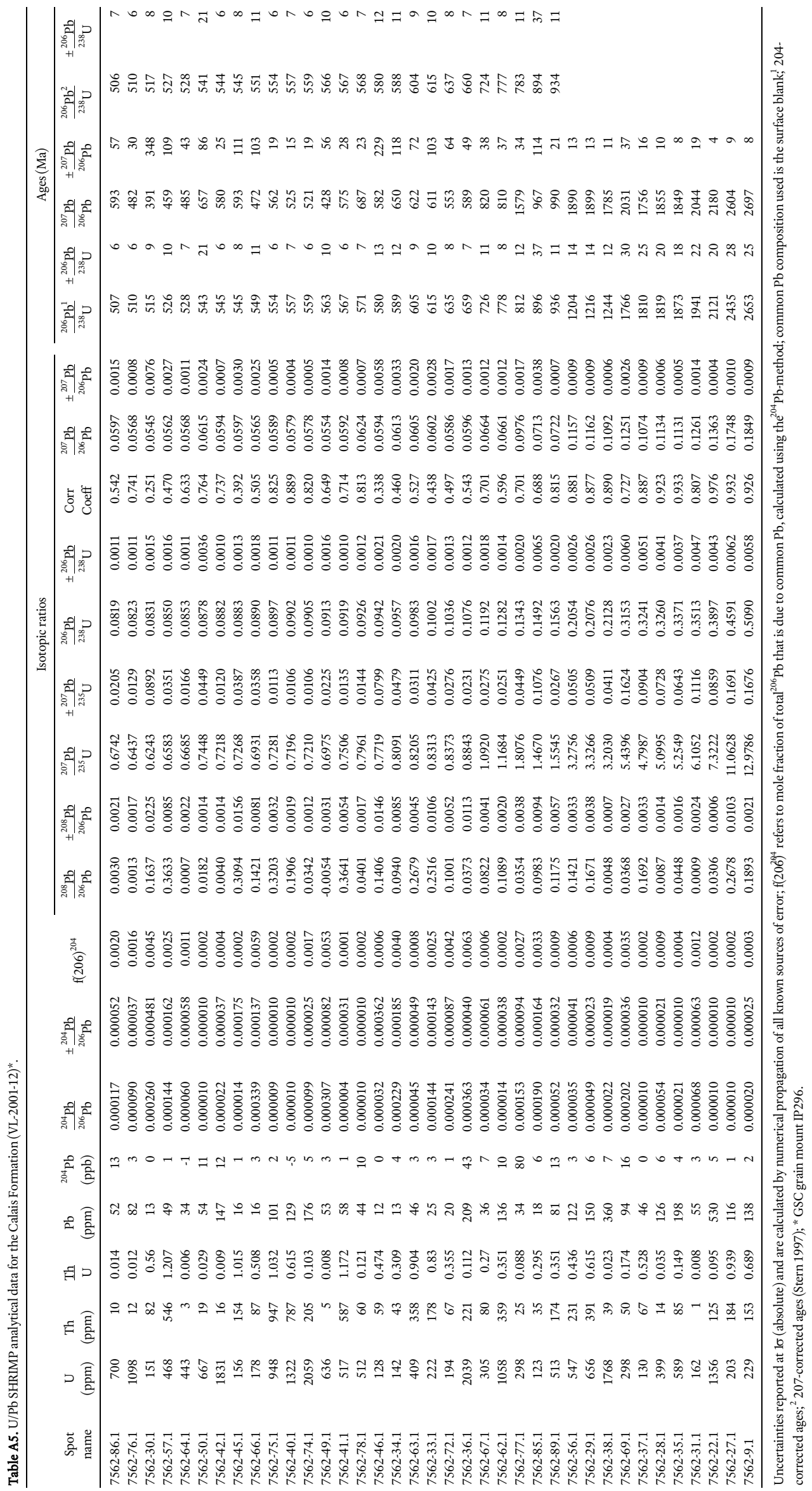




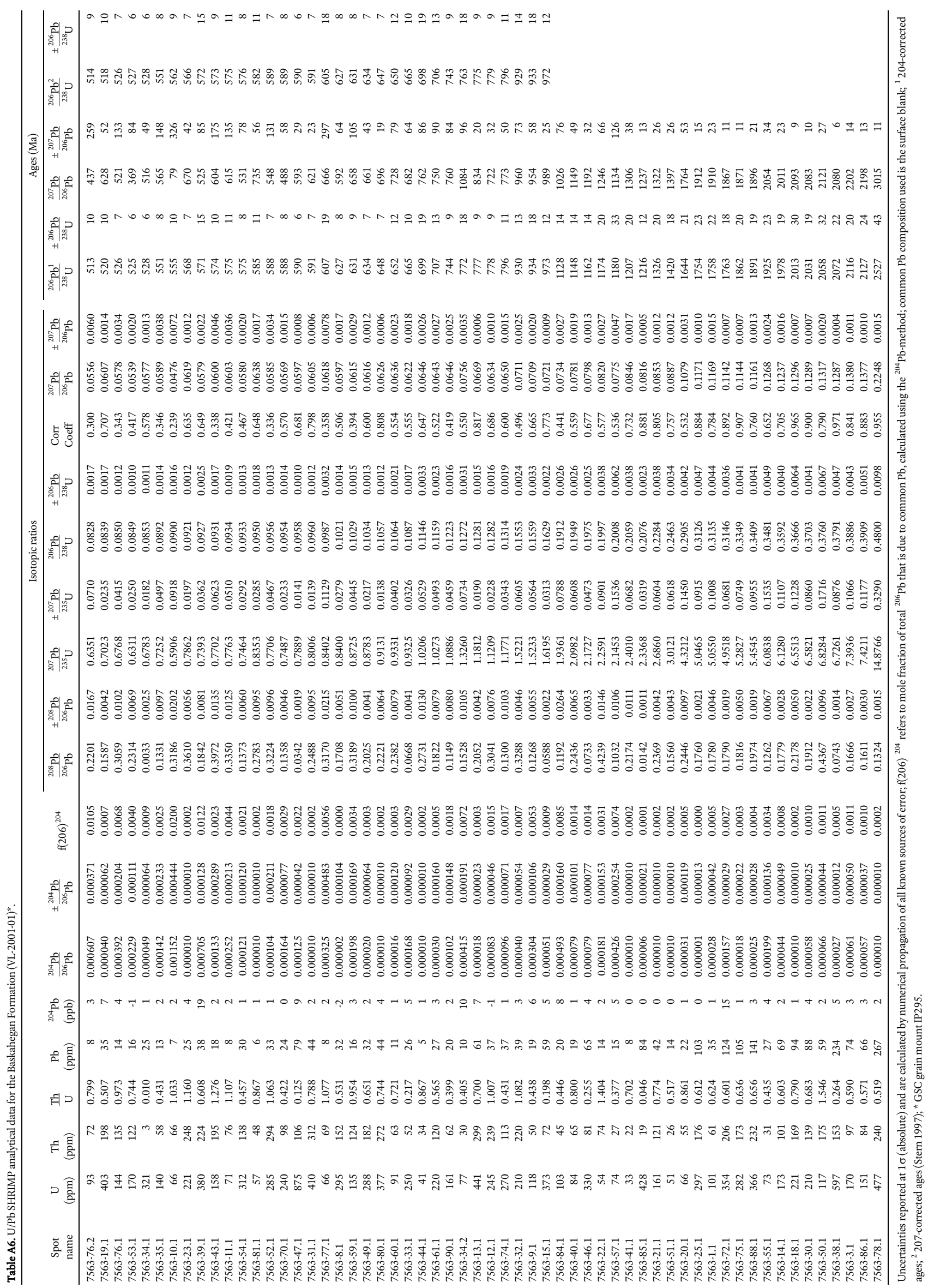


啇高

을

月

E 言窎

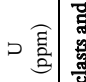

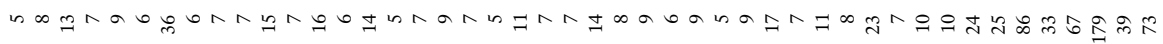

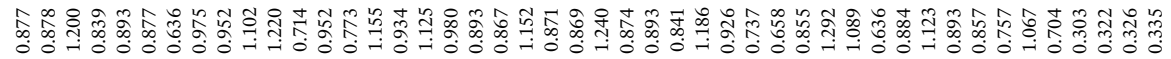

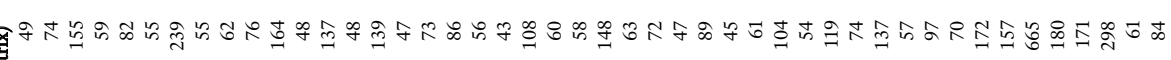

穷窟

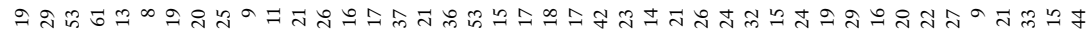

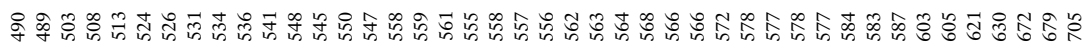

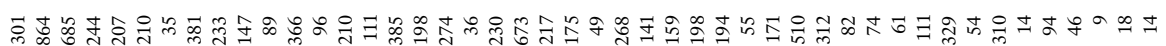

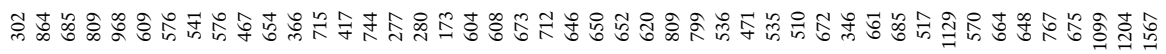

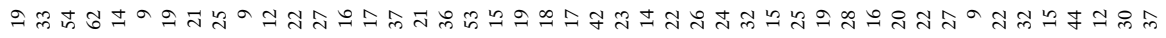

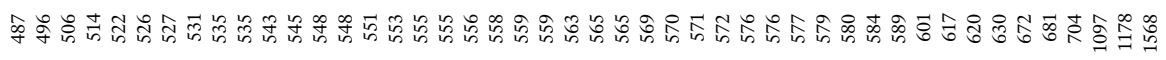

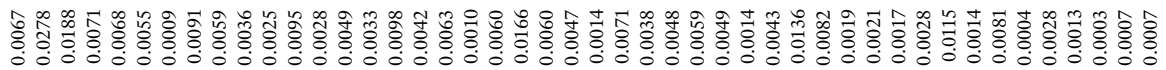

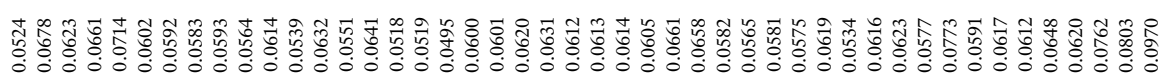

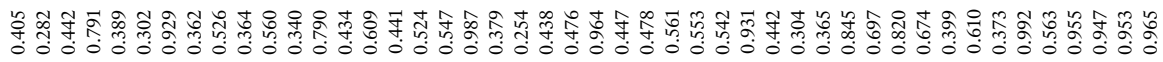

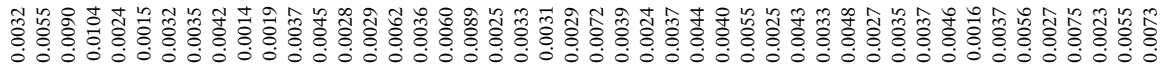

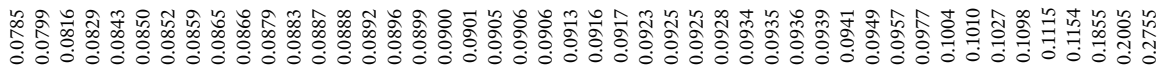

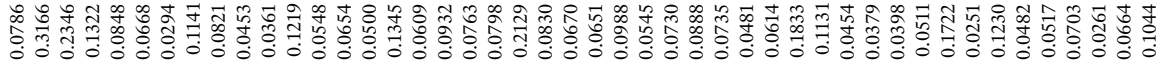

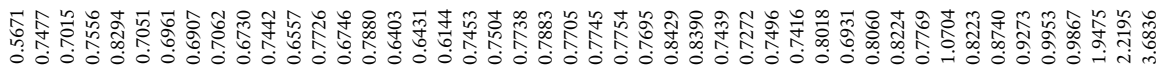

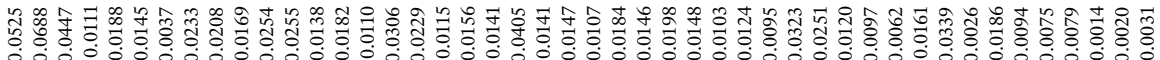

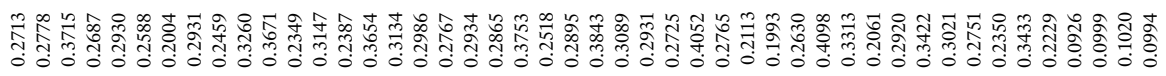

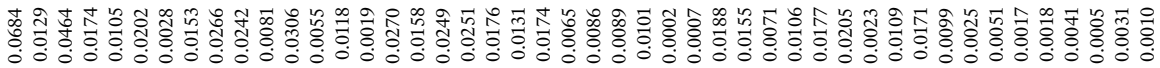

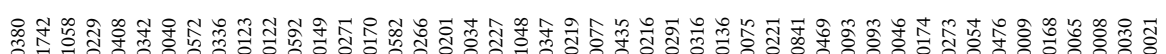
o

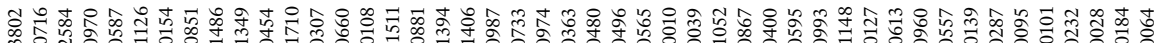

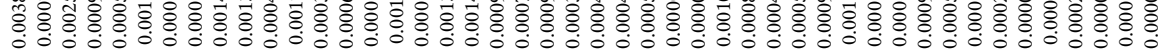
Ltan

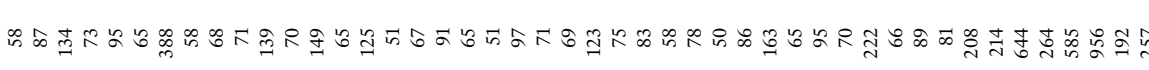

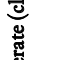

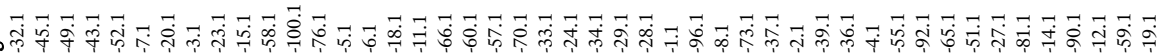

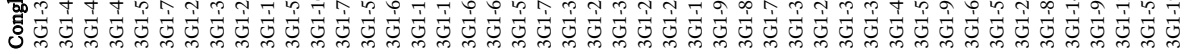

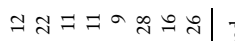

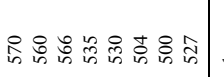

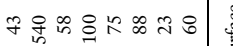

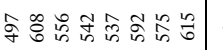

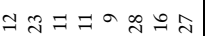

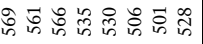

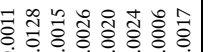

들

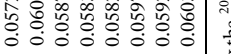

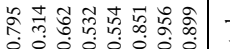

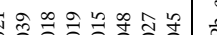

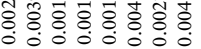

茟

สิ

过0

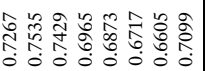

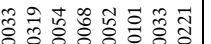

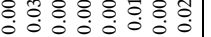

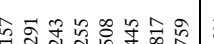

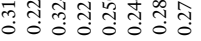

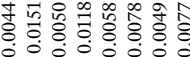

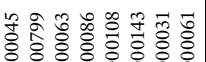

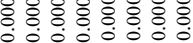

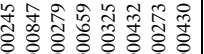

管:

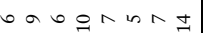

펨표

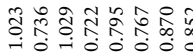

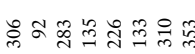

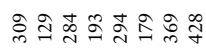
잉

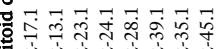

政 